\title{
Direct Oral Anticoagulants for the Prevention of Stroke in Patients with Nonvalvular Atrial Fibrillation: Understanding Differences and Similarities
}

\author{
Paul P. Dobesh ${ }^{1} \cdot$ John Fanikos ${ }^{2}$
}

Published online: 14 September 2015

(C) The Author(s) 2015. This article is published with open access at Springerlink.com

\begin{abstract}
The presence of atrial fibrillation (AF), the most common sustained cardiac arrhythmia, significantly increases the risk for stroke. Current guidelines recommend that the vitamin $\mathrm{K}$ antagonist warfarin or direct oral anticoagulants (DOACs), such as the approved direct thrombin inhibitor dabigatran and the approved direct factor Xa inhibitors apixaban, rivaroxaban, and edoxaban, should be used for thromboprophylaxis in patients with nonvalvular $\mathrm{AF}$ at risk for stroke or systemic embolic events (SEE). Warfarin, the mainstay of stroke prevention in AF, increases the risk of major bleeding. Furthermore, warfarin therapy comes with several limitations including frequent monitoring and the need for dose adjustments, unpredictable pharmacokinetics and pharmacodynamics, and the potential for significant drug-drug and food-drug interactions. The DOACs were developed to overcome these limitations while maintaining or surpassing warfarin's efficacy and safety profiles. All four DOACs have similar or better efficacy and safety compared with warfarin and are therefore valuable alternatives for the prevention of stroke and SEE in patients with nonvalvular AF. Understanding the subtle differences in the DOACs' pharmacology, phase 3 study designs, and trial outcomes will allow for a more tailored approach in selecting the right oral anticoagulant for each patient.
\end{abstract}

Paul P. Dobesh

pdobesh@unmc.edu

1 College of Pharmacy, University of Nebraska Medical Center, 986045 Nebraska Medical Center, Omaha, NE 68198-6045, USA

2 Department of Pharmacy, Brigham and Women's Hospital, Boston, MA, USA

\section{Key Points}

Direct oral anticoagulants (DOACs) offer an attractive alternative to traditional vitamin $\mathrm{K}$ antagonists for reduction in the risk of stroke in patients with nonvalvular atrial fibrillation (AF).

The DOACs provided similar or better clinical outcomes compared with vitamin $\mathrm{K}$ antagonists in large, randomized, phase 3 trials.

There are a number of clinical issues that should be considered when evaluating clinical trials that evaluated DOACs in patients with AF. The difference in each trial design makes a comparison of these agents difficult.

\section{Introduction}

Atrial fibrillation (AF) is the most common sustained cardiac arrhythmia in older adults [1, 2]. AF is independently associated with an approximate 5-fold increase in a patient's stroke risk [3], with the risk of stroke attributable to AF increasing with age [4]. Compared with those without AF, the relative risk (RR) of stroke has been calculated as 4.0-, 2.6-, 3.3-, and 4.5-fold more likely for patients aged 50-59, 60-69, 70-79, and 80-89, respectively [5]. In addition, the presence of AF at stroke onset is associated with increased mortality and recurrence rates [6]. Thirty-day and 1-year mortality rates in patients presenting with $\mathrm{AF}$ at stroke onset were 32.5 and $49.5 \%$, 
respectively, compared with 16.2 and $27.1 \%$ for patients without $\mathrm{AF}$ at stroke onset [6]. Moreover, recurrence rates within the first year of follow-up were higher for patients who presented with $\mathrm{AF}$ at the time of stroke onset (6.6 vs. $4.4 \% ; p=0.046$ ) [6]. As such, thromboprophylaxis is a common, though often underused [7], component to the overall management of patients with AF.

Recent guidelines for the management of nonvalvular AF recommend that warfarin or direct-acting oral anticoagulants (DOACs) be used for the prevention of stroke and systemic embolic events (SEE) in patients at risk for such events $[8,9]$. The antithrombotic agent should be selected for the individual patient based on risk factors, cost, tolerability, patient preference, potential for drug interactions, and other clinical characteristics. The approved DOACs include the direct thrombin inhibitor dabigatran and the direct factor Xa inhibitors rivaroxaban, apixaban, and edoxaban [10-13]. This review will discuss the study designs, safety, efficacy, and relevance to clinical practice of anticoagulant options for prevention of stroke in patients with nonvalvular AF, including traditional therapy with warfarin and the DOACs dabigatran, rivaroxaban, apixaban, and edoxaban.

\section{Warfarin Therapy}

The vitamin $\mathrm{K}$ antagonist (VKA) warfarin has been used in clinical practice for many years and has well-established efficacy. Warfarin, dose-adjusted to an international normalized ratio (INR) of 2.0 to 3.0, reduces the risk of stroke in patients with AF by $64 \%$ [95\% confidence interval (CI) 49-74\%] compared with placebo/no treatment and by $39 \%$ (95\% CI 22-52\%) compared with antiplatelet therapy [14]. Despite its long history of use and proven efficacy, warfarin is associated with inherent limitations such as unpredictable pharmacokinetics (PK) and pharmacodynamics (PD) as well as the potential for significant drug-drug and drug-food interactions [15]. Therefore, patients undergoing warfarin therapy require frequent physician visits for INR monitoring and dose adjustments to maintain a therapeutic level of anticoagulation and reduce the risk of bleeding. In a post hoc analysis of a randomized trial comparing warfarin therapy with antiplatelet therapy in patients with AF, the time in the therapeutic INR range (TTR) varied extensively between the 526 centers analyzed from 15 countries [16]. For patients on warfarin therapy, at centers below the median TTR of $65 \%$, there was no decrease in vascular events compared with dual antiplatelet therapy (RR, 0.93; $95 \%$ CI
$0.70-1.24, p=0.61)$ [16]. However, patients receiving oral anticoagulant therapy at centers with a TTR above $65 \%$ showed a decrease in vascular events (RR, 2.14; $95 \%$ CI 1.61-2.85; $p<0.0001)$. In a meta-analysis of eight randomized controlled trials in which warfarin was used for stroke prevention in patients with $\mathrm{AF}$, the INR remained in the therapeutic range only $55-68 \%$ of the time [17]. Major bleeding rates varied across studies and per year, ranging from 1.40 to $3.40 \%$, but typically decreased with an increased TTR [17]. Thus, suboptimal INR control can lead to either increased risk of thromboembolic events or increased risk of bleeding.

Bleeding episodes can be a serious and costly consequence associated with warfarin therapy. In an analysis of medical and pharmacy claims from 47,437 patients, $0.4 \%$ of patients had an intracranial hemorrhage, $1.9 \%$ had a major gastrointestinal bleed, and $3.8 \%$ of patients experienced a minor gastrointestinal bleed within 30 days of a warfarin claim [18]. Mean (standard deviation) unadjusted all-cause healthcare costs were increased in patients with at least one intracranial hemorrhage [US $\$ 41,903$ (US $\$ 56,654$ )], or major gastrointestinal bleed [US\$40,586 (US\$65,164)] compared with patients with minor gastrointestinal bleed [US $\$ 24,347$ (US\$56,488)] or no bleeding events [US\$24,129 (US\$36,425)] [18]. Additional costs associated with warfarin therapy can be the result of medication errors that lead to adverse drug reactions [19]. In the ORBIT-AF (Outcomes Registry for Better Informed Treatment of Atrial Fibrillation) Registry, prior bleed (31.1 vs. 16.7, $p<0.0001$ ), high bleeding risk (20.3 vs. $10.3, p<0.0001)$, and frequent falls or frailty (20.7 vs. $7.4, p<0.0001)$ were more frequently listed as contraindications to receiving anticoagulant therapy in patients with a $\mathrm{CHADS}_{2}$ score $\geq 2$ compared with patients with a $\mathrm{CHADS}_{2}$ score $<2$ [20], despite the greater risk of stroke attributed to these patients. Thus, there has been interest in developing alternative agents that are easier to manage while providing reduced risk for bleeding and fewer drug and food interactions compared with warfarin therapy.

\section{Direct Oral Anticoagulants Phase 3 Studies}

Dabigatran, rivaroxaban, apixaban, and edoxaban have all demonstrated safety and efficacy compared with warfarin in large, randomized clinical trials for the reduction of risk of stroke and SEE in patients with nonvalvular AF [21]. All patients included in these trials were at an increased risk of stroke due to one or more risk factors, such as previous stroke or transient ischemic attack (TIA), heart failure, diabetes mellitus, hypertension, or age $\geq 75$ years. 


\subsection{Study Design}

The clinical trial designs for the studies are summarized in Table 1. All four trials were noninferiority studies. In RELY (Randomized Evaluation of Long Term Anticoagulant Therapy with Dabigatran etexilate), patients were randomized to either fixed doses of dabigatran, administered in a blinded fashion, or dose-adjusted warfarin, which was administered open-label [22]. The other three trials used a double-blind, double-dummy design [23-25]. The ROCKET AF (Rivaroxaban Once Daily Oral Direct Factor Xa Inhibition Compared with Vitamin K Antagonism for Prevention of Stroke and Embolism Trial in Atrial Fibrillation) and ARISTOTLE (Apixaban for the Prevention of Stroke in Subjects With Atrial Fibrillation) trials tested a single dose compared with warfarin, while RE-LY and ENGAGE AF-TIMI 48 (Effective Anticoagulation with Factor Xa Next Generation in Atrial Fibrillation-Thrombolysis in Myocardial Infarction 48) trials evaluated two different doses. A twice-daily dosing regimen was used in RE-LY and ARISTOTLE, while ROCKET AF and
ENGAGE AF had once-daily dosing. Finally, decreased doses of drug were included in three of the trials. In ARISTOTLE, a decreased dose of apixaban $(2.5 \mathrm{mg}$ twice daily) was used in a subset of patients with two or more of the following characteristics: age $\geq 80$ years, body weight $\leq 60 \mathrm{~kg}$, or a serum creatinine level of $\geq 1.5 \mathrm{mg} / \mathrm{dL}$ [23]. A reduced dose of rivaroxaban (15 $\mathrm{mg}$ once daily) was used in patients with a creatinine clearance $(\mathrm{CrCl})$ of 30-49 mL/min in ROCKET AF [23]. In ENGAGE AF, patients randomized to either the lower-dose regimen (30 mg edoxaban once daily) or higher-dose regimen (60 mg edoxaban once daily) who had an anticipated increased drug exposure due to a $\mathrm{CrCl}$ of $30-50 \mathrm{~mL} / \mathrm{min}$, body weight $\leq 60 \mathrm{~kg}$, or concomitant administration of the strong p-glycoprotein (P-gp) inhibitors verapamil, quinidine, or dronedarone also received a $50 \%$ reduced dose [26]. In addition, the $50 \%$ dose reduction could occur at any time during the ENGAGE AF trial if any of the abovementioned three criteria were met [26].

The trials had many similar inclusion criteria, requiring the presence of $\mathrm{AF}$ documented by electrocardiography

Table 1 Comparison of clinical trial design for DOAC clinical trials in patients with atrial fibrillation [22-25]

\begin{tabular}{|c|c|c|c|c|}
\hline Parameter & $\begin{array}{l}\text { RE-LY } \\
\text { (dabigatran) }\end{array}$ & $\begin{array}{l}\text { ROCKET AF } \\
\text { (rivaroxaban) }\end{array}$ & $\begin{array}{l}\text { ARISTOTLE } \\
\text { (apixaban) }\end{array}$ & $\begin{array}{l}\text { ENGAGE AF-TIMI } 48 \\
\text { (edoxaban) }\end{array}$ \\
\hline Study design & $\begin{array}{l}\text { Randomized, dabigatran dosage- } \\
\text { blinded, open-label warfarin, } \\
\text { parallel-arm, noninferiority } \\
\text { study }\end{array}$ & $\begin{array}{l}\text { Randomized, double- } \\
\text { blind, double- } \\
\text { dummy, event- } \\
\text { driven, parallel- } \\
\text { arm, noninferiority } \\
\text { study }\end{array}$ & $\begin{array}{l}\text { Randomized, double-blind, } \\
\text { double-dummy, parallel-arm, } \\
\text { noninferiority study }\end{array}$ & $\begin{array}{l}\text { Randomized, double-blind, } \\
\text { double-dummy trial, parallel- } \\
\text { arm, noninferiority study }\end{array}$ \\
\hline $\begin{array}{l}\text { Primary } \\
\text { endpoint } \\
\text { (analysis } \\
\text { population) }\end{array}$ & $\begin{array}{l}\text { Stroke or systemic embolism } \\
\text { (ITT) }\end{array}$ & $\begin{array}{l}\text { Stroke or systemic } \\
\text { embolism }(\mathrm{PP})\end{array}$ & $\begin{array}{l}\text { Stroke or systemic embolism } \\
\text { (ITT) }\end{array}$ & $\begin{array}{l}\text { Stroke or systemic embolism } \\
(\text { mITT })\end{array}$ \\
\hline Dosage & $\begin{array}{l}\text { Dabigatran } 110 \mathrm{mg} \text { or } 150 \mathrm{mg} \\
\text { BID, or warfarin dose-adjusted } \\
\text { to a target INR of } 2.0-3.0\end{array}$ & $\begin{array}{l}\text { Rivaroxaban } 20 \mathrm{mg} \\
\text { once daily or } \\
\text { warfarin dose- } \\
\text { adjusted to a target } \\
\text { INR of } 2.0-3.0\end{array}$ & $\begin{array}{l}\text { Apixaban } 5 \mathrm{mg} \text { BID or } \\
\text { warfarin dose-adjusted to a } \\
\text { target INR of } 2.0-3.0\end{array}$ & $\begin{array}{l}\text { Edoxaban } 30 \mathrm{mg} \text { or } 60 \mathrm{mg} \text { once } \\
\text { daily, or warfarin dose- } \\
\text { adjusted to a target INR of } \\
2.0-3.0\end{array}$ \\
\hline $\begin{array}{l}\text { Dose } \\
\text { reduction }\end{array}$ & None & $\begin{array}{l}15 \mathrm{mg} \text { once daily for } \\
\text { patients with a } \\
\mathrm{CrCl} \text { of } 30-49 \mathrm{~mL} / \\
\text { min }\end{array}$ & $\begin{array}{l}2.5 \mathrm{mg} \text { BID in a subset of } \\
\text { patients with } 2 \text { or more of the } \\
\text { following criteria: age } \geq 80, \\
\text { body weight } \leq 60 \mathrm{~kg} \text {, or serum } \\
\text { creatinine } \geq 1.5 \mathrm{mg} / \mathrm{dL}\end{array}$ & $\begin{array}{l}50 \% \text { dose reduction was given } \\
\text { to patients with } \mathrm{CrCl} \\
30-50 \mathrm{~mL} / \mathrm{min} \text {, body weight } \\
\leq 60 \mathrm{~kg} \text {, or concomitant use of } \\
\text { verapamil, quinidine, or } \\
\text { dronedarone at randomization } \\
\text { or during study }\end{array}$ \\
\hline $\begin{array}{l}\text { Follow-up } \\
\text { visits }\end{array}$ & $\begin{array}{l}\text { INR measured at least monthly; } \\
14 \text { days after randomization, } \\
\text { at } 1 \text { and } 3 \text { months, every } \\
3 \text { months thereafter in the first } \\
\text { year, and then every } 4 \text { months } \\
\text { until the study ended }\end{array}$ & $\begin{array}{l}1,2 \text {, and } 4 \text { weeks and } \\
\text { monthly thereafter }\end{array}$ & $\begin{array}{l}\text { Monthly for INR monitoring; } \\
\text { assessment every } 3 \text { months; } \\
30 \text { days after last dose }\end{array}$ & $\begin{array}{l}\text { INR measured monthly; study } \\
\text { visits on days } 8,15,29 \text {, and } 60 \\
\text { at month } 3 \text {, and at least every } \\
3 \text { months thereafter }\end{array}$ \\
\hline
\end{tabular}

$B I D$ twice daily, $\mathrm{CrCl}$ creatinine clearance, $D O A C$ direct oral anticoagulant, INR international normalized ratio, ITT intention to treat population, $m I T T$ modified intention to treat, $P P$ per protocol, as-treated population during treatment 
(ECG) (Table 2). However, there are some important differences in the populations enrolled, resulting in differences in risk across trials. The RE-LY and ARISTOTLE trials included patients with a left ventricular ejection fraction of $<40$ and $\leq 40 \%$, respectively, values that are consistent with a diagnosis of heart failure [22, 23]. However, ROCKET AF included patients with a leftventricular ejection fraction of $\leq 35 \%$, indicative of a greater risk of cardiac dysfunction [24]. ROCKET AF and ENGAGE AF recruited patients at higher risk for stroke than RE-LY or ARISTOTLE [22-25]. The presence of AF must have been documented within 30 days before randomization in ROCKET AF, at screening or within 6 months before randomization in RE-LY, and 12 months prior to enrollment in ARISTOTLE and ENGAGE AF [2225]. Patients with atrial flutter were also included in ARISTOTLE [23].
Exclusion criteria were generally similar across all trials (Table 3). Patients were ineligible if they had experienced a recent stroke (within 14 days in RE-LY or ROCKET AF; 7 days in ARISTOTLE; 30 days in ENGAGE AF) [2225]. All trials excluded patients with severe renal dysfunction ( $\mathrm{CrCl}<30 \mathrm{~mL} / \mathrm{min}$ ), except ARISTOTLE, which excluded patients with $\mathrm{CrCl}<25 \mathrm{~mL} / \mathrm{min}$ or a serum creatinine $>2.5 \mathrm{mg} / \mathrm{dL}$ [23]. Bleeding risk exclusions for recent trauma or major surgery, gastrointestinal bleeding, hemorrhagic disorders, and intracranial bleeding were well defined in RE-LY, ROCKET AF, and ENGAGE AF [22, 24, 25]. In ARISTOTLE, patients with a bleeding risk believed to be a contraindication to oral anticoagulation were excluded [23]. Patients were allowed $\leq 100 \mathrm{mg}$ daily aspirin in the RE-LY, ROCKET AF, and ENGAGE AF trials [22, 24, 25], and $<165 \mathrm{mg}$ daily aspirin in the ARISTOTLE trial [23].

Table 2 Inclusion criteria for clinical trials of DOACs in patients with atrial fibrillation [22-25]

\begin{tabular}{|c|c|c|c|c|}
\hline Parameter & $\begin{array}{l}\text { RE-LY } \\
\text { (dabigatran) }\end{array}$ & $\begin{array}{l}\text { ROCKET AF } \\
\text { (rivaroxaban) }\end{array}$ & $\begin{array}{l}\text { ARISTOTLE } \\
\text { (apixaban) }\end{array}$ & $\begin{array}{l}\text { ENGAGE AF-TIMI } 48 \\
\text { (edoxaban) }\end{array}$ \\
\hline $\begin{array}{l}\text { Atrial } \\
\text { fibrillation }\end{array}$ & Nonvalvular AF & Nonvalvular AF & $\begin{array}{l}\text { Nonvalvular AF or atrial } \\
\text { flutter not due to a } \\
\text { reversible cause }\end{array}$ & Nonvalvular AF \\
\hline $\begin{array}{l}\text { Documented } \\
\text { by }\end{array}$ & $\begin{array}{l}\text { 12-lead ECG, rhythm strip, } \\
\text { pacemaker/ICD ECG, or } \\
\text { Holter ECG; the duration of } \\
\text { AF should be } \geq 30 \mathrm{~s} \text {. ECG } \\
\text { (not marker channels or } \\
\text { mode switch episodes) from } \\
\text { pacemakers and defibrillators } \\
\text { can be used to document only } \\
1 \text { episode of paroxysmal or } \\
\text { persistent AF }\end{array}$ & $\begin{array}{l}\text { 12-lead ECG, rhythm strip, } \\
\text { Holter, or pacemaker } \\
\text { interrogation and have } \\
\text { medical evidence of AF } \\
\text { before the qualifying ECG } \\
\text { evidence }\end{array}$ & $\begin{array}{l}\text { ECG, or as an episode lasting } \\
\text { at least } 1 \text { min on a rhythm } \\
\text { strip, Holter recording, or } \\
\text { intracardiac ECG (from an } \\
\text { implanted pacemaker or } \\
\text { defibrillator) }\end{array}$ & $\begin{array}{l}\text { 12-lead ECG, continuous } \\
\text { ECG recording, rhythm } \\
\text { strip, intracardiac ECG, } \\
\text { pacemaker or implantable } \\
\text { cardiac defibrillator } \\
\text { interrogation }\end{array}$ \\
\hline Timeframe & $\begin{array}{l}\text { On the day of screening or } \\
\text { randomization; or } \\
\text { symptomatic episode within } \\
6 \text { months before } \\
\text { randomization; or } \\
\text { symptomatic or } \\
\text { asymptomatic paroxysmal or } \\
\text { persistent AF on } 2 \text { separate } \\
\text { occasions, at least } 1 \text { day } \\
\text { apart, one of which is within } \\
6 \text { months before } \\
\text { randomization }\end{array}$ & $\begin{array}{l}\text { Within } 30 \text { days before } \\
\text { randomization and medical } \\
\text { evidence within } 1 \text { year } \\
\text { before and at least } 1 \text { day } \\
\text { before the ECG }\end{array}$ & $\begin{array}{l}\text { On the day of screening; or on } \\
2 \text { separate occasions at least } \\
2 \text { weeks apart in the } \\
12 \text { months prior to } \\
\text { enrollment }\end{array}$ & Within the prior 12 months \\
\hline $\begin{array}{l}\text { Stroke risk } \\
\text { factors }\end{array}$ & $\begin{array}{l}\mathrm{CHADS}_{2} \text { index score } \geq 1^{\mathrm{a}} \text {; or } \\
\text { age } \geq 65 \text { years and } 1 \text { of the } \\
\text { following: diabetes mellitus } \\
\text { on treatment; or documented } \\
\text { coronary artery disease; or } \\
\text { hypertension requiring } \\
\text { medical treatment }\end{array}$ & $\mathrm{CHADS}_{2}$ index score $\geq 2$ & $\mathrm{CHADS}_{2}$ index score $\geq 1$ & $\mathrm{CHADS}_{2}$ index score $\geq 2$ \\
\hline Age & $\geq 18$ years & $\geq 18$ years & $\geq 18$ years & $\geq 21$ years \\
\hline
\end{tabular}

$A F$ atrial fibrillation, $D O A C$ direct oral anticoagulant, $E C G$ electrocardiogram, $I C D$ implantable cardioverter defibrillator

${ }^{a}$ Patients with only diabetes mellitus or hypertension must be $\geq 65$ years of age 
Table 3 Exclusion criteria for clinical trials of DOACs in patients with atrial fibrillation [22-25]

\begin{tabular}{|c|c|c|c|c|}
\hline Parameter & $\begin{array}{l}\text { RE-LY } \\
\text { (dabigatran) }\end{array}$ & $\begin{array}{l}\text { ROCKET AF } \\
\text { (rivaroxaban) }\end{array}$ & $\begin{array}{l}\text { ARISTOTLE } \\
\text { (apixaban) }\end{array}$ & $\begin{array}{l}\text { ENGAGE AF-TIMI } 48 \\
\text { (edoxaban) }\end{array}$ \\
\hline \multirow[t]{2}{*}{ Stroke } & $\begin{array}{l}\text { Severe, disabling stroke } \\
\text { within the previous } 6 \\
\text { months }\end{array}$ & $\begin{array}{l}\text { Severe, disabling stroke } \\
\text { within } 3 \text { months; TIA } \\
\text { within } 3 \text { days before the } \\
\text { randomization visit }\end{array}$ & $\begin{array}{l}\text { Ischemic stroke within } 7 \\
\text { days }\end{array}$ & $\begin{array}{l}\text { Stroke, acute MI, acute } \\
\text { coronary syndrome, or } \\
\text { percutaneous intervention } \\
\text { within the previous } 30 \text { days }\end{array}$ \\
\hline & \multicolumn{4}{|c|}{$\begin{array}{l}\text { Or any stroke within } 14 \text { days before the randomization } \\
\text { visit }\end{array}$} \\
\hline Oral anticoagulation & \multicolumn{4}{|c|}{ Indication for anticoagulant therapy for a condition other than atrial fibrillation } \\
\hline Contraindications & \multicolumn{3}{|c|}{ Contraindication to warfarin } & $\begin{array}{l}\text { Contraindication to } \\
\text { anticoagulant agents }\end{array}$ \\
\hline Life expectancy & $\begin{array}{l}<\text { Expected duration of } \\
\text { the trial }\end{array}$ & $<2$ years & $\leq 1$ year & $<1$ year \\
\hline $\begin{array}{l}\text { Cardiac-related } \\
\text { conditions }\end{array}$ & \multicolumn{3}{|c|}{$\begin{array}{l}\text { History of heart valve disorder; transient atrial fibrillation caused by a reversible } \\
\text { disorder (e.g., thyrotoxicosis, PE, recent surgery, MI); active endocarditis }\end{array}$} & $\begin{array}{l}\text { History of heart valve } \\
\text { disorder (with the } \\
\text { exception of bioprosthetic } \\
\text { heart valve or valve } \\
\text { repair); transient atrial } \\
\text { fibrillation caused by a } \\
\text { reversible disorder (e.g., } \\
\text { thyrotoxicosis, PE, recent } \\
\text { surgery, MI); active } \\
\text { endocarditis }\end{array}$ \\
\hline Planned AF procedure & $\begin{array}{l}\text { Any planned ablation or } \\
\text { surgery }\end{array}$ & $\begin{array}{l}\text { Planned cardioversion } \\
\text { (electrical or } \\
\text { pharmacological) }\end{array}$ & Any planned & $\begin{array}{l}\text { Chronic anticoagulation } \\
\text { therapy will be } \\
\text { discontinued if a planned } \\
\text { pharmacologic, electrical, } \\
\text { or surgical therapy were to } \\
\text { be successful in converting } \\
\text { and maintaining normal } \\
\text { sinus rhythm }\end{array}$ \\
\hline $\begin{array}{l}\text { Uncontrolled } \\
\text { hypertension }\end{array}$ & \multicolumn{2}{|c|}{$\begin{array}{l}\text { Systolic blood pressure } \geq 180 \mathrm{mmHg} \text { or diastolic blood } \\
\text { pressure } \geq 100 \mathrm{mmHg}\end{array}$} & $\begin{array}{l}\text { Systolic blood pressure } \\
>180 \mathrm{mmHg} \text { or } \\
\text { diastolic blood pressure } \\
>100 \mathrm{mmHg}\end{array}$ & $\begin{array}{l}\text { Systolic blood pressure } \\
>170 \mathrm{mmHg} \text { or diastolic } \\
\text { blood pressure } \\
>100 \mathrm{mmHg}\end{array}$ \\
\hline Bleeding risk & \multicolumn{2}{|c|}{$\begin{array}{l}\text { History of or condition associated with increased } \\
\text { bleeding risk }\end{array}$} & $\begin{array}{l}\text { Bleeding risk that is a } \\
\text { contraindication to oral } \\
\text { anticoagulation }\end{array}$ & $\begin{array}{l}\text { History of or condition } \\
\text { associated with increased } \\
\text { bleeding risk }\end{array}$ \\
\hline $\begin{array}{l}\text { Planned surgery or } \\
\text { intervention }\end{array}$ & $\begin{array}{l}\text { Within the next } 3 \\
\text { months }\end{array}$ & Any planned & Any planned & Any planned \\
\hline $\begin{array}{l}\text { Trauma or major } \\
\text { surgery }\end{array}$ & $\begin{array}{l}\text { Within the previous } \\
\text { month }\end{array}$ & $\begin{array}{l}\text { Within } 30 \text { days before } \\
\text { randomization }\end{array}$ & Not defined & Within the previous 10 days \\
\hline $\begin{array}{l}\text { Intracranial, intraocular, } \\
\text { spinal, or atraumatic } \\
\text { intra-articular bleed }\end{array}$ & Any history & Any history & Not defined & Any history \\
\hline GI bleed & $\begin{array}{l}\text { Within the past year; } \\
\text { symptomatic or } \\
\text { endoscopically } \\
\text { documented } \\
\text { gastroduodenal ulcer } \\
\text { disease in the previous } \\
30 \text { days }\end{array}$ & $\begin{array}{l}\text { Within } 6 \text { months before } \\
\text { randomization }\end{array}$ & Not defined & Within the previous year \\
\hline Hemorrhagic disorder & Any history & Chronic & Not defined & Any history \\
\hline $\begin{array}{l}\text { Concurrent aspirin } \\
\text { excluded }\end{array}$ & $>100 \mathrm{mg}$ daily & $>100 \mathrm{mg}$ daily & $>165 \mathrm{mg}$ daily & $>100 \mathrm{mg}$ daily \\
\hline
\end{tabular}


Table 3 continued

\begin{tabular}{|c|c|c|c|c|}
\hline Parameter & $\begin{array}{l}\text { RE-LY } \\
\text { (dabigatran) }\end{array}$ & $\begin{array}{l}\text { ROCKET AF } \\
\text { (rivaroxaban) }\end{array}$ & $\begin{array}{l}\text { ARISTOTLE } \\
\text { (apixaban) }\end{array}$ & $\begin{array}{l}\text { ENGAGE AF-TIMI } 48 \\
\text { (edoxaban) }\end{array}$ \\
\hline $\begin{array}{l}\text { Concurrent } \\
\text { antiplatelet/fibrinolytic } \\
\text { therapy }\end{array}$ & $\begin{array}{l}\text { Fibrinolytic agents } \\
\text { within } 48 \text { hours of } \\
\text { study entry }\end{array}$ & $\begin{array}{l}\text { Aspirin in combination with } \\
\text { thienopyridines within } 5 \\
\text { days before } \\
\text { randomization, IV } \\
\text { antiplatelet agents within } 5 \\
\text { days before } \\
\text { randomization, } \\
\text { fibrinolytics within } 10 \\
\text { days before randomization }\end{array}$ & $\begin{array}{l}\text { Simultaneous treatment } \\
\text { with both aspirin and a } \\
\text { thienopyridine (e.g., } \\
\text { clopidogrel) }\end{array}$ & $\begin{array}{l}\text { Aspirin plus thienopyridine, } \\
\text { fibrinolytics }\end{array}$ \\
\hline $\begin{array}{l}\text { Anti-inflammatory } \\
\text { agents }\end{array}$ & N/A & $\begin{array}{l}\text { Anticipated need for chronic } \\
\text { treatment with NSAIDs }\end{array}$ & $\begin{array}{l}\text { NSAIDs should be used } \\
\text { with caution }\end{array}$ & $\begin{array}{l}\text { Chronic nonaspirin NSAID } \\
\text { use ( }>4 \text { days/week) }\end{array}$ \\
\hline Concomitant therapy & N/A & $\begin{array}{l}\text { Cytochrome P450 3A4 } \\
\text { inhibitors (ketoconazole or } \\
\text { protease inhibitors) or } \\
\text { inducers (rifampin/ } \\
\text { rifampicin) prohibited }\end{array}$ & $\begin{array}{l}\text { Cytochrome P450 3A4 } \\
\text { inhibitors } \\
\text { (ketoconazole or } \\
\text { protease inhibitors), } \\
\text { other antithrombotic } \\
\text { agents, GP IIb/IIIa } \\
\text { inhibitors }\end{array}$ & $\begin{array}{l}\text { Cyclosporine, potent P-gp } \\
\text { inhibitors, nonstudy } \\
\text { anticoagulants }\end{array}$ \\
\hline Laboratory parameters & $\begin{array}{l}\text { Hemoglobin }<10 \mathrm{~g} / \mathrm{dL} \\
\text { Platelet count } \\
<100,000 / \mathrm{mm}^{3}\end{array}$ & $\begin{array}{l}\text { Hemoglobin }<10 \mathrm{~g} / \mathrm{dL} \\
\text { Platelet count }<90,000 / \\
\mathrm{mm}^{3}\end{array}$ & $\begin{array}{l}\text { Hemoglobin }<9 \mathrm{~g} / \mathrm{dL} \\
\text { Platelet count } \\
\leq 100,000 / \mathrm{mm}^{3}\end{array}$ & $\begin{array}{l}\text { Hemoglobin }<10 \mathrm{~g} / \mathrm{dL} \\
\text { Platelet count }<100,000 / \\
\mathrm{mm}^{3}\end{array}$ \\
\hline Renal function & $\begin{array}{l}\text { Estimated } \mathrm{CrCl} \\
\leq 30 \mathrm{~mL} / \mathrm{min}\end{array}$ & $\begin{array}{l}\text { Calculated } \mathrm{CrCl}<30 \mathrm{~mL} / \\
\text { min }\end{array}$ & $\begin{array}{l}\mathrm{SCr}>2.5 \mathrm{mg} / \mathrm{dL} \text { or } \\
\text { calculated } \mathrm{CrCl} \\
<25 \mathrm{~mL} / \mathrm{min}\end{array}$ & $\begin{array}{l}\text { Calculated } \mathrm{CrCl}<30 \mathrm{~mL} / \\
\text { min }\end{array}$ \\
\hline Hepatic function & $\begin{array}{l}\text { Active liver disease } \\
\text { (hepatitis A, B, or C), } \\
\text { ALT, AST, Alk Phos } \\
>2 x \text { the ULN }\end{array}$ & $\begin{array}{l}\text { Known significant liver } \\
\text { disease or ALT }>3 x \text { the } \\
\text { ULN }\end{array}$ & $\begin{array}{l}\text { ALT or AST }>2 \mathrm{x} \text { ULN } \\
\text { or a total bilirubin } \\
>1.5 \mathrm{x} \text { ULN }\end{array}$ & $\begin{array}{l}\text { Active or persistent liver } \\
\text { disease, positive hepatitis } \\
\text { B or C test, ALT or AST } \\
>2 \mathrm{x} \text { ULN or total bilirubin } \\
\geq 1.5 \mathrm{x} \text { ULN }\end{array}$ \\
\hline
\end{tabular}

$A F$ atrial fibrillation, Alk Phos alkaline phosphatase, $A L T$ alanine aminotransferase, $A S T$ aspartate aminotransferase, $C r C l$ creatinine clearance, $D O A C$ direct oral anticoagulant, $G I$ gastrointestinal, $G P$ glycoprotein, $I V$ intravenous, $M I$ myocardial infarction, NIA not available, NSAID nonsteroidal anti-inflammatory drug, $P E$ pulmonary embolism, $S C r$ serum creatinine, TIA transient ischemic attack, $U L N$ upper limit of normal

All four studies assessed the efficacy and safety of the DOACs for stroke prevention in patients with nonvalvular $\mathrm{AF}$, which was defined as AF in the absence of rheumatic mitral stenosis, a mechanical or bioprosthetic heart valve, or mitral valve repair [8]. It should be noted that mild mitral stenosis was not excluded in ENGAGE AF or ARISTOTLE, and subjects with AF and valvular heart diseases such as mitral valve prolapse, mitral valve regurgitation, and aortic valve disease were allowed in ENGAGE AF [23, 25]. In ROCKET AF, hemodynamically significant mitral valve stenosis was excluded, and hemodynamically significant valvular disease was excluded in RE-LY [22, 24].

\subsection{Primary Endpoint Analyses}

In all trials, the primary efficacy endpoint was noninferiority compared with warfarin for stroke or SEE [22-25]. Of note, there were differences in the analysis populations for the primary efficacy endpoint: RE-LY and ARISTOTLE reported noninferiority for their intent-to-treat (ITT) populations, ROCKET AF reported for the per-protocol population, and ENGAGE AF analyzed the modified ITT (mITT) population (Table 1) [22-25]; thus the ROCKET AF and ENGAGE AF trials' primary efficacy endpoint analyses were performed on on-treatment patients. In RE-LY, ARISTOTLE, and ENGAGE AF, major bleeding was the primary safety endpoint [22-24]. All studies used an adapted version of the International Society of Thrombosis and Hemostasis (ISTH) criteria for major bleeding [22-25]. In the ROCKET AF trial, the composite of major and clinically relevant nonmajor (CRNM) bleeding was the primary safety endpoint [24].

\section{Patient Characteristics}

In ROCKET AF, more patients in the warfarin group than patients in the rivaroxaban group had a $\mathrm{CHADS}_{2}$ score of 6 (2.2 vs. $1.7 \%$, respectively) and a previous myocardial 
infarction (MI) (18.0 vs. $16.6 \%$, respectively) [24]. Overall, patients in ROCKET AF and ENGAGE AF were at a greater risk of stroke than patients enrolled in other trials, with higher $\mathrm{CHADS}_{2}$ scores overall [24, 25]. Patients enrolled in ROCKET AF and ENGAGE AF trials also included higher percentages of patients with diabetes, hypertension, and congestive heart failure. More than half the patients in ROCKET AF had a history of stroke or TIA, with lower rates in each of the other three trials. The proportion of patients with paroxysmal AF was higher in RE-LY and in ENGAGE AF than in the other trials.

\section{Clinical Trial Results and Approved Dosing Recommendations}

\subsection{Dabigatran Etexilate}

At a dose of $110 \mathrm{mg}$ twice daily, dabigatran demonstrated noninferiority to warfarin for the prevention of stroke and SEE in patients with nonvalvular AF $(p<0.001$ for noninferiority; Table 5) [22]. Dabigatran $150 \mathrm{mg}$ twice daily was associated with lower rates of stroke and systemic embolism than warfarin ( $p<0.001$ for superiority) and significantly reduced the risk for ischemic stroke (RR, 0.76; $95 \%$ CI 0.60-0.98; $p=0.03$ ) [21]. Both doses of dabigatran significantly reduced the risk for hemorrhagic stroke compared with warfarin (RR, 0.31; $95 \% \mathrm{CI}$ $0.17-0.56, p<0.001$ for dabigatran $110 \mathrm{mg}$; RR, 0.26; $95 \%$ CI $0.14-0.49 ; p<0.001$ for dabigatran $150 \mathrm{mg}$ ). Event rates for dabigatran were updated following publication of the primary data to reflect inclusion of events potentially related to stroke as well as the addition of patients who did not undergo randomization and several deaths that occurred after the end of the study [27, 28]. The updated event rates, which did not change the primary conclusions of the study, are captured in Table 5.

The rate of major bleeding was similar in patients who received warfarin or dabigatran $150 \mathrm{mg}$ twice daily ( $p=0.31$ ), and lower in patients who received dabigatran $110 \mathrm{mg}$ twice daily (RR 0.80; $95 \%$ CI 0.69-0.93, $p=0.003$ compared with warfarin; Table 6) [22]. There was a significantly higher rate of major gastrointestinal bleeding with dabigatran $150 \mathrm{mg}$ than warfarin $(\mathrm{RR}, 1.50$;

Table 4 Characteristics and patient demographics of phase 3 clinical trials [22-25]

\begin{tabular}{|c|c|c|c|c|}
\hline Parameter & $\begin{array}{l}\text { RE-LY } \\
\text { (dabigatran) }\end{array}$ & $\begin{array}{l}\text { ROCKET AF } \\
\text { (rivaroxaban) }\end{array}$ & $\begin{array}{l}\text { ARISTOTLE } \\
\text { (apixaban) }\end{array}$ & $\begin{array}{l}\text { ENGAGE AF-TIMI } 48 \\
\text { (edoxaban) }\end{array}$ \\
\hline Patients $(n)$ & 18,113 & 14,264 & 18,201 & 21,105 \\
\hline Median age (years) & 71 (mean) & 73 & 70 & 72 \\
\hline Male sex $(\%)$ & 64 & 60 & 65 & 62 \\
\hline Mean weight (kg) & 83 & $28 \mathrm{~kg} / \mathrm{m}^{2}$ (BMI) & 82 (median) & NR \\
\hline Low body weight $(\%)^{\mathrm{a}}$ & 2.1 & 28 & 11 & 10 \\
\hline Paroxysmal AF (\%) & 33 & 18 & 15 & 25 \\
\hline Persistent or permanent AF (\%) & 67 & $81^{\mathrm{b}}$ & 85 & 75 \\
\hline \multicolumn{5}{|l|}{$\mathrm{CHADS}_{2}$ score } \\
\hline Mean & 2.1 & 3.5 & 2.1 & 2.8 \\
\hline $0-1(\%)$ & 32 & $0^{\mathrm{c}}$ & 34 & - \\
\hline $2(\%)$ & 36 & 13 & 36 & $77(\leq 3)$ \\
\hline $3-6(\%)$ & 32 & 87 & 30 & $23(4-6)$ \\
\hline Previous stroke or TIA (\%) & 20 & 55 & 19 & 28 \\
\hline Heart failure $(\%)$ & 32 & 63 & 35 & 57 \\
\hline Diabetes mellitus (\%) & 23 & 40 & 25 & 36 \\
\hline Hypertension (\%) & 79 & 91 & 87 & 94 \\
\hline Previous VKA use (\%) & 50 & 62 & 57 & 59 \\
\hline Previous aspirin use $(\%)$ & 40 & 37 & 31 & 29 \\
\hline Mean TTR (\%) & 64 & 55 & 62 & 65 \\
\hline Median TTR (\%) & NR & 58 & 66 & 68 \\
\hline Median follow-up (years) & 2.0 & 1.9 & 1.8 & 2.8 \\
\hline
\end{tabular}

$A F$ atrial fibrillation, $N R$ not reported, $T I A$ transient ischemic attack, TTR time in therapeutic range, $V K A$ vitamin $\mathrm{K}$ antagonist

${ }^{a}$ For RE-LY, $<50 \mathrm{~kg}$; ROCKET AF, $\leq 70 \mathrm{~kg}$; ARISTOTLE and ENGAGE AF-TIMI 48, $\leq 60 \mathrm{~kg}$

b $1 \%$ were newly diagnosed or new onset

c 3 patients had a score of 1 


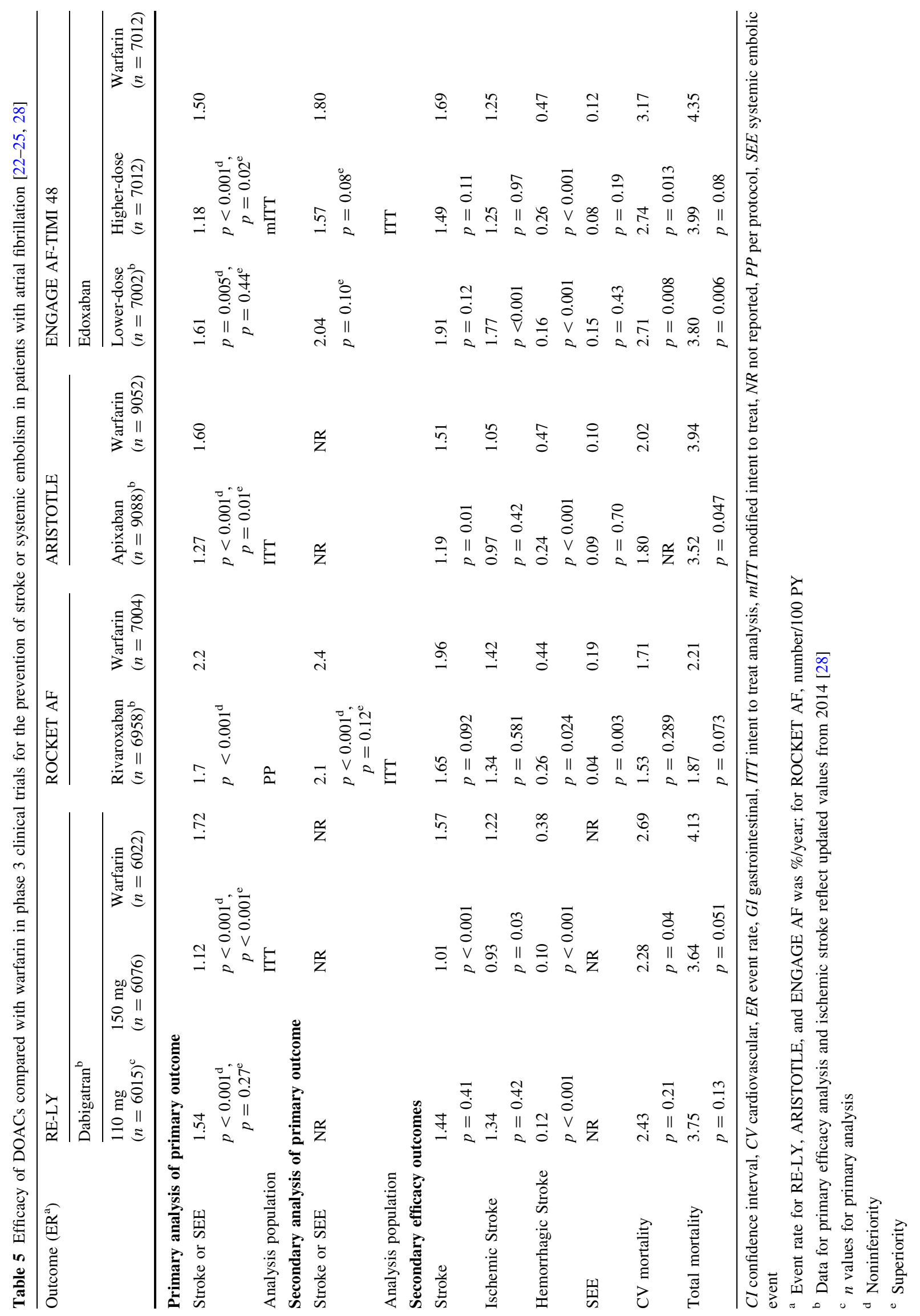


Table 6 Safety of DOACs compared with warfarin in phase 3 clinical trials for the prevention of stroke or systemic embolism in patients with atrial fibrillation $[22-25,28]$

\begin{tabular}{|c|c|c|c|c|c|c|c|c|c|c|}
\hline \multirow[t]{3}{*}{$\overline{\text { Outcome }\left(\mathrm{ER}^{\mathrm{a}}\right)}$} & \multicolumn{3}{|l|}{ RE-LY } & \multicolumn{2}{|l|}{ ROCKET AF } & \multicolumn{2}{|c|}{ ARISTOTLE } & \multicolumn{3}{|c|}{ ENGAGE AF-TIMI 48} \\
\hline & \multicolumn{2}{|c|}{ Dabigatran $^{\mathrm{b}}$} & \multirow[t]{2}{*}{ Warfarin } & \multirow[t]{2}{*}{ Rivaroxaban } & \multirow[t]{2}{*}{$\overline{\text { Warfarin }}$} & \multirow[t]{2}{*}{ Apixaban } & \multirow[t]{2}{*}{ Warfarin } & \multicolumn{2}{|l|}{ Edoxaban } & \multirow[t]{2}{*}{ Warfarin } \\
\hline & $110 \mathrm{mg}$ & $150 \mathrm{mg}$ & & & & & & $\begin{array}{l}\text { Lower- } \\
\text { dose }\end{array}$ & $\begin{array}{l}\text { Higher- } \\
\text { dose }\end{array}$ & \\
\hline Major bleeding & 2.92 & 3.40 & 3.61 & 3.6 & 3.4 & 2.13 & 3.09 & 1.61 & 2.75 & 3.43 \\
\hline & $p=0.003$ & $p=0.41$ & & $p=0.58$ & & $p<0.001$ & & $p<0.001$ & $p<0.001$ & \\
\hline $\begin{array}{l}\text { Major or CRNM } \\
\text { bleeding }\end{array}$ & NR & NR & NR & $\begin{array}{l}14.9 \\
p=0.44\end{array}$ & 14.5 & $\begin{array}{l}4.07 \\
p<0.001\end{array}$ & 6.01 & $\begin{array}{l}7.97 \\
p<0.001\end{array}$ & $\begin{array}{l}11.10 \\
p<0.001\end{array}$ & 13.02 \\
\hline $\begin{array}{l}\text { Intracranial } \\
\text { bleeding }\end{array}$ & $\begin{array}{l}0.23 \\
p<0.001\end{array}$ & $\begin{array}{l}0.30 \\
p<0.001\end{array}$ & 0.74 & $\begin{array}{l}0.5 \\
p=0.02\end{array}$ & 0.7 & $\begin{array}{l}0.33 \\
p<0.001\end{array}$ & 0.80 & $\begin{array}{l}0.26 \\
p<0.001\end{array}$ & $\begin{array}{l}0.39 \\
p<0.001\end{array}$ & 0.85 \\
\hline GI bleeding & $\begin{array}{l}1.12 \\
p=0.43\end{array}$ & $\begin{array}{l}1.51 \\
p<0.001\end{array}$ & 1.02 & $\begin{array}{l}3.2 \\
p<0.001\end{array}$ & 2.2 & $\begin{array}{l}0.76 \\
p=0.37\end{array}$ & 0.86 & $\begin{array}{l}0.82 \\
p<0.001\end{array}$ & $\begin{array}{l}1.51 \\
p=0.03\end{array}$ & 1.23 \\
\hline Any bleeding & $\begin{array}{l}14.62 \\
p<0.001\end{array}$ & $\begin{array}{l}16.42 \\
p=0.002\end{array}$ & 18.15 & NR & NR & $\begin{array}{l}18.1 \\
p<0.001\end{array}$ & 25.8 & $\begin{array}{l}10.68 \\
p<0.001\end{array}$ & $\begin{array}{l}14.15 \\
p<0.001\end{array}$ & 16.40 \\
\hline
\end{tabular}

$C I$ confidence interval, $C R N M$ clinically relevant nonmajor, DOAC direct oral anticoagulant, $G I$ gastrointestinal, $N R$ not reported

All $p$ values for superiority

${ }^{a}$ Event rate for RE-LY, ARISTOTLE, and ENGAGE AF was \%/year; for ROCKET AF, number/100 PY

${ }^{\mathrm{b}}$ Data for major bleeding reflect updated values from 2014 [28]

$95 \%$ CI 1.19-1.89, $p<0.001)$ [22]. The rate of intracranial bleeding was significantly reduced in patients receiving dabigatran $150 \mathrm{mg}$ (RR, 0.40; $95 \%$ CI $0.27-0.60$, $p<0.001)$ or dabigatran $110 \mathrm{mg}(\mathrm{RR}, 0.31 ; 95 \% \mathrm{CI}$ $0.20-0.47, \quad p<0.001)$ compared with warfarin [22]. Annualized rates of other adverse events were similar between groups, except the rate of dyspepsia was increased with dabigatran $110 \mathrm{mg}(11.8 \%)$ and $150 \mathrm{mg}(11.3 \%)$ compared with warfarin $(5.8 \% ; p<0.001$ for both comparisons) [22]. Updated major bleeding rates are reflected in Table 6 [28].

Dabigatran is approved in the USA, Canada, and Europe at an oral dose of $150 \mathrm{mg}$ twice daily for patients with a $\mathrm{CrCl}$ of $>30 \mathrm{~mL} / \mathrm{min}$ for the reduction of the risk of stroke and SEE $[11,29,30]$. In the USA, patients with a $\mathrm{CrCl}$ of $15-30 \mathrm{~mL} / \mathrm{min}$ should receive an oral dose of $75 \mathrm{mg}$ twice daily, and dabigatran should be avoided in patients with a $\mathrm{CrCl}<15 \mathrm{~mL} / \mathrm{min}$ or on dialysis [11]. In Canada and Europe, a reduced dose of $110 \mathrm{mg}$ is recommended for patients with a $\mathrm{CrCl}$ of $30-50 \mathrm{~mL} / \mathrm{min}[29,30]$. A reduced dose of $75 \mathrm{mg}$ twice daily may be given to patients with a $\mathrm{CrCl}$ between 30 and $50 \mathrm{~mL} / \mathrm{min}$ receiving dronedarone or ketoconazole. However, dose adjustments are not necessary for administration with other P-gp inhibitors [11]. Patients with a $\mathrm{CrCl}<30 \mathrm{~mL} / \mathrm{min}$ who are receiving concomitant P-gp inhibitors should not receive dabigatran [11]. Dabigatran should not be administered with potent P-gp inducers [11].

\subsection{Rivaroxaban}

In ROCKET AF, rivaroxaban demonstrated noninferiority to warfarin for the prevention of stroke or SEE in patients with nonvalvular $\mathrm{AF}$ ( $p<0.001$ for noninferiority; Table 5) [24]. Rivaroxaban demonstrated superiority in the on-treatment analysis $(p=0.015)$, but not in the ITT analysis $(p=0.12)$, despite the fact that there is only a difference of 28 patients between these two analysis groups (Table 5). Rates of hemorrhagic stroke were significantly reduced in the rivaroxaban group compared with the warfarin group.

Major and CRNM bleeding rates were similar between groups $(p=0.44)$ (Table 6) [24]. Patients in the rivaroxaban group experienced lower rates of intracranial hemorrhage [hazard ratio (HR), 0.67; $95 \%$ CI 0.47-0.93; $p=0.02]$ and fatal bleeding (HR, 0.50; $95 \%$ CI $0.31-0.79 ; p=0.003)$ than patients in the warfarin group [24]. It should be noted that there was more major gastrointestinal bleeding $(3.2$ vs. $2.2 \% ; p<0.001)$ and a higher need for transfusion (2.6 vs. $2.15 \% ; p=0.04$ ) with the use of rivaroxaban compared with warfarin [24]. Rates of other adverse events were similar between groups.

The reduced dose of rivaroxaban (15 $\mathrm{mg}$ once daily) or rivaroxaban placebo, for patients with moderate renal insufficiency, was used in $21 \%$ of patients in both groups [24]. The primary efficacy and safety outcomes were consistent with the outcomes demonstrated with those who received full dose. 
In patients with a $\mathrm{CrCl}>50 \mathrm{~mL} / \mathrm{min}$, rivaroxaban should be administered with the evening meal at a dose of $20 \mathrm{mg}$ once daily [12]. Patients with a $\mathrm{CrCl}$ of $15-50 \mathrm{~mL} / \mathrm{min}$ should receive a reduced dose of $15 \mathrm{mg}$ once daily at the evening meal [12]. Rivaroxaban should not be given with combined P-gp and strong cytochrome P450 3A4 (CYP3A4) inhibitors or combined P-gp and strong CYP3A4 inducers [12].

\subsection{Apixaban}

Apixaban demonstrated a lower annualized rate of stroke or SEE than warfarin in patients with AF $(p<0.001$ for noninferiority; $p=0.01$ for superiority; Table 5) [23]. There was a significant reduction in risk for hemorrhagic stroke among patients who received apixaban compared with warfarin.

Major bleeding rates were lower in the apixaban group compared with the warfarin group (HR, 0.69; $95 \%$ CI $0.60-0.80, p<0.001$ ) (Table 6). Similarly, major or CRNM bleeding occurred less frequently in patients who received apixaban than patients who received warfarin (HR, 0.68; $95 \%$ CI 0.61-0.75, $p<0.001$ ). Rates of other adverse events were similar between groups.

The reduced dose of apixaban $2.5 \mathrm{mg}$ twice daily was administered in $4.7 \%$ of patients in the apixaban group [23]. The primary efficacy and safety outcomes were not significantly different for patients who received the $2.5 \mathrm{mg}$ twicedaily dose compared with those who received the full dose.

For the reduction of risk of stroke and SEE in nonvalvular AF, patients should receive oral apixaban $5 \mathrm{mg}$ twice daily [10]. A reduced oral dose of $2.5 \mathrm{mg}$ twice daily should be given to patients in whom at least two of the following are true: age $\geq 80$ years, body weight $\leq 60 \mathrm{~kg}$, or serum creatinine $\geq 1.5 \mathrm{mg} / \mathrm{dL}$ [10]. Patients receiving strong dual inhibitors of CYP3A4 and P-gp should be given a reduced dose of $2.5 \mathrm{mg}$ twice daily. However, patients already taking apixaban $2.5 \mathrm{mg}$ twice daily should avoid coadministration of apixaban with strong dual inhibitors of CYP3A4 and P-gp [10]. Patients taking strong dual inducers of CYP3A4 and P-gp should not receive apixaban [10].

\subsection{Edoxaban}

Both the higher- $(60 \mathrm{mg})$ and lower-dose $(30 \mathrm{mg})$ regimens of edoxaban demonstrated noninferiority to warfarin in prevention of stroke or SEE in patients with $\mathrm{AF}$ (HR, 0.79; 97.5\% CI 0.63-0.99, $p<0.001$ and HR, 1.07; $97.5 \%$ CI 0.87-1.31, $p=0.005$, respectively; Table 5) [25]. Furthermore, higher-dose edoxaban demonstrated superiority ( $p=0.02)$ to warfarin when the mITT population was analyzed, but this superiority was lost when the ITT population was tested $(p=0.08)$. Treatment with either dose of edoxaban led to significantly reduced risks for hemorrhagic stroke compared with warfarin (HR, 0.54; $95 \%$ CI $0.38-0.77, p<0.001$ and HR, 0.33; $95 \% \mathrm{CI}$ $0.22-0.50, p<0.001$ for higher- and lower-dose edoxaban, respectively). While the efficacy and safety evaluation of edoxaban was stratified by varying degrees of renal function for regulatory approval [13], a published analysis in this population is not yet available.

Annualized rates of major bleeding were decreased in patients who received either the higher- or lower-dose regimens of edoxaban compared with warfarin (HR, 0.80; $95 \%$ CI $0.71-0.91, p<0.001$; HR, 0.47; $95 \%$ CI $0.41-0.45, p<0.001)$ for the higher and lower dose, respectively) (Table 6) [25].

Rates of stroke or SEE in patients who received the $50 \%$ dose reduction were $2.32 \%$ for the higher-dose group (30 mg), $3.14 \%$ for the lower-dose group (15 mg), and $2.68 \%$ for patients with similar characteristics in the warfarin group. The resulting HRs and corresponding $95 \%$ CIs were not significantly different to those for the full dosing groups [25]. However, the resulting reductions in the risk for major bleeding were significantly greater for patients in the higher- and lower-dose edoxaban regimens who received a $50 \%$ dose reduction compared to those who did not $(p=0.02$ and $p<0.01$ for interaction, respectively). Major bleeding rates for reduced-dose edoxaban patients were $3.05 \%$ for higher-dose group (30 mg) and $1.50 \%$ for lower-dose group (15 mg) versus $4.85 \%$ for warfarin patients with similar characteristics [25].

For the prevention of stroke and SEE in patients with nonvalvular AF, edoxaban $60 \mathrm{mg}$ once daily is approved in the USA [13] and Japan [31], and is approved in other countries, including the European Union [32]. Edoxaban should not be used in patients with $\mathrm{CrCl}>95 \mathrm{~mL} / \mathrm{min}$ [13]. A reduced, once-daily dose of edoxaban $30 \mathrm{mg}$ should be used in patients with $\mathrm{CrCl} 15-50 \mathrm{~mL} / \mathrm{min}$. Edoxaban should not be coadministered with rifampin [13].

\section{Subpopulations}

Patients with a history of stroke or TIA are at an increased risk of reoccurrence [33]. The DOAC trials included patients who had a previous stroke or TIA. There were 3623 patients $(20 \%)$ in the RE-LY trial that had a previous stroke or TIA. Of these patients, $2.78 \%$ per year in the warfarin group experienced a stroke or SEE, $2.32 \%$ per year in the dabigatran $110 \mathrm{mg}$ group (RR, 0.84; 95\% CI $0.58-1.20)$, and $2.07 \%$ per year in the dabigatran $150 \mathrm{mg}$ group (RR, 0.75; $95 \%$ CI 0.52-1.08) [34]. In ROCKET AF, 7468 patients $(52 \%)$ had a previous stroke or TIA. In 
rivaroxaban-treated patients, 2.79 events/100 PY of stroke or SEE compared with 2.96 events/100 PY occurred in warfarin-treated patients (HR, 0.94; $95 \%$ CI 0.77-1.16) [35]. Prior stroke or TIA occurred in 3436 patients (19\%) in the ARISTOTLE trial. In these patients, stroke or SEE rates were $2.5 \%$ per year for apixaban-treated patients and $3.2 \%$ per year for warfarin-treated patients [23]. In the ENGAGE AF trial, 5973 patients $(28 \%)$ had a previous stroke or TIA. The rate of the primary efficacy outcome was $2.44 \%$ per year with higher-dose edoxaban, $3.19 \%$ per year with lower-dose edoxaban, and $2.85 \%$ per year with warfarin [25]. These results identify DOACs as an option in patients with AF and a history of stroke or TIA.

All of the DOACs are dependent on renal function for drug clearance, with dabigatran exhibiting the greatest renal dependence. Roughly $80 \%$ of the absorbed dose of dabigatran is cleared by the kidneys [11], 66 and $35 \%$ of orally administered doses of rivaroxaban and edoxaban, respectively, are eliminated by kidneys [12,13]. Apixaban has the least renal dependence of the DOACs, with $27 \%$ of the oral dose cleared renally [10]. Patients with renal dysfunction may experience impaired excretion of parent drugs, which can result in excessive drug accumulation and altered drug distribution and elimination [36]. Due to these considerations, the US Food and Drug Administration (FDA) has issued recommendations regarding the evaluation of drugs in patients with renal impairment [37], and thus, all studies included patients with moderate renal impairment $(\mathrm{CrCl} 30-50 \mathrm{~mL} / \mathrm{min})$. In RE-LY, 3505 patients $(19 \%)$ had a $\mathrm{CrCl}$ of $<50 \mathrm{~mL} / \mathrm{min}$. In this subset of patients, the rate of stroke or SEE was $2.15 \%$ per year in patients treated with dabigatran $110 \mathrm{mg}, 1.52 \%$ per year with dabigatran $150 \mathrm{mg}$, and $2.78 \%$ per year with warfarin [22]. Patients in the ROCKET AF trial with moderate renal impairment $(\mathrm{CrCl}$ of $30-49 \mathrm{~mL} / \mathrm{min})$ received a reduced dose of rivaroxaban (15 mg daily). Moderate renal impairment was seen in $2950(21 \%)$ patients in ROCKET $\mathrm{AF}$. The rate of stroke or SEE was higher in patients with moderate renal impairment than patients with $\mathrm{CrCl}>50 \mathrm{~mL} / \mathrm{min} \quad(2.32$ vs. 1.57 events/100 PY in rivaroxaban-treated patients and 2.77 vs. 2.00 events $/ 100$ $\mathrm{PY}$ in warfarin-treated patients, respectively) [38]. In the ARISTOTLE trial, 3017 patients had moderate or severe renal impairment $(\mathrm{CrCl} \leq 50 \mathrm{~mL} / \mathrm{min})$. The rates of stroke or SEE were $2.1 \%$ per year in apixaban-treated patients and $2.7 \%$ per year in warfarin-treated patients [23]. Major bleeding was lower in apixaban-treated patients than warfarin-treated patients (3.2 vs. $6.4 \%$, respectively) [23]. As previously described, patients in ENGAGE AF received a $50 \%$ decreased dose of edoxaban if they had $\mathrm{CrCl}$ of $30-50 \mathrm{~mL} / \mathrm{min}$, along with those who had a body weight $\leq 60 \mathrm{~kg}$, or concomitant administration of strong P-gp inhibitors [25]. Within either dosing regimen of edoxaban, the $50 \%$ dose reduction did not impact the efficacy of edoxaban, while it did lead to a significantly greater risk reduction for major bleeding compared with those who received full dose edoxaban. For patients with a $\mathrm{CrCl}$ of $30-50 \mathrm{~mL} / \mathrm{min}$, the rates of stroke or SEE were similar (2.3 and $2.7 \%$ for edoxaban $60 \mathrm{mg}$ and warfarin, respectively) [13]. Patients with a $\mathrm{CrCl}$ of $30-50 \mathrm{~mL} / \mathrm{min}$ receiving higher-dose edoxaban had a lower major bleeding rate relative to warfarin $(3.8 \%$ compared with $5.1 \%$, respectively; HR, 0.76; 95\% CI 0.58-0.99) [13]. Additional post hoc analyses stratified by renal function indicated that the rates of ischemic stroke were increased with the use of edoxaban relative to warfarin in nonvalvular AF patients with $\mathrm{CrCl}>95 \mathrm{~mL} / \mathrm{min}$ due to lower plasma concentrations of edoxaban $[13,39]$. Therefore, edoxaban should not be used in patients with $\mathrm{AF}$ and a $\mathrm{CrCl}>95 \mathrm{~mL} / \mathrm{min}$.

The efficacy and safety of DOACs is similar in patients $\geq 75$ years of age compared with patients $<75$ years of age [40]. The rates of stroke or SEE are reduced relative to warfarin, and associated with a lower risk of bleeding in phase 3 trials [22-25]. Edoxaban, rivaroxaban, and apixaban exhibited no differences in efficacy or safety in elderly patients compared with younger patients [23-25]. Dabigatran has a significant interaction of age by treatment, with both 110 and $150 \mathrm{mg}$ of dabigatran producing a higher risk of major bleeding in patients $\geq 75$ compared with patients $<75$ years of age [41]. Edoxaban decreased the absolute risk of major bleeding, including intracranial hemorrhage, in elderly patients compared with warfarin [42].

All trials included patients who had previously been on a VKA as well as VKA-naïve patients. In the RE-LY trial, 9123 patients were VKA-naïve and 8989 patients were VKA-experienced. The annualized rate of stroke and SEE in VKA-naïve patients was $1.57,1.07$, and $1.69 \%$ for dabigatran $110 \mathrm{mg}$, dabigatran $150 \mathrm{mg}$, and warfarin, respectively ( $p=0.65$ for dabigatran $110 \mathrm{mg}$ to warfarin; $p=0.005$ for dabigatran $150 \mathrm{mg}$ to warfarin) [43]. In VKA-experienced patients, the primary endpoint occurred in $1.51,1.15$, and $1.74 \%$ per year, respectively $(p=0.32$ for dabigatran $110 \mathrm{mg}$ to warfarin; $p=0.007$ for dabigatran $150 \mathrm{mg}$ to warfarin). Major bleeding rates in dabigatran-treated VKA-naïve patients were lower (dabigatran $110 \mathrm{mg}$ ) or similar (dabigatran $150 \mathrm{mg}$ ) to warfarin [43]. In ROCKET AF, 6367 patients were VKA-naïve and 7897 patients were VKA-experienced. Rates of stroke and SEE were similar between rivaroxaban- or warfarin-treated patients in VKA-naïve (2.32 vs. 2.87 events/100 PY) and VKA-experienced patients (1.98 vs. 2.09 events/100 PY) [44]. During the first seven days, rivaroxaban patients experienced more bleeding than warfarin patients in VKAnaïve and -experienced patients. However, after 30 days, rivaroxaban was associated with less bleeding in VKAnaïve patients and similar bleeding in VKA-experienced 
patients [44]. In ARISTOTLE, 10,401 patients were VKAexperienced while 7800 were VKA-naïve. The primary efficacy outcome occurred in $1.1 \%$ per year of VKA-experienced patients treated with apixaban and $1.5 \%$ per year of VKA-experienced patients treated with warfarin [23]. In VKA-naïve patients, $1.5 \%$ per year experienced the primary outcome when treated with apixaban compared with $1.8 \%$ per year of patients treated with warfarin. Annualized major bleeding rates were lower in patients treated with apixaban compared with warfarin in VKAnaïve (2.2 vs. $3.0 \%)$ and VKA-experienced patients (2.1 vs. $3.2 \%$ ) [23]. There were 8663 VKA-naïve and 12,441 VKA-experienced patients in ENGAGE AF. The rates of the primary efficacy endpoints were $1.49,1.97$, and $2.12 \%$ per year with higher-dose edoxaban, lower-dose edoxaban, and warfarin, respectively, in VKA-naïve patients [25]. In VKA-experienced patients the primary efficacy endpoint rates were $1.62,2.08$, and $1.60 \%$ per year, respectively. Major bleeding rates were decreased with high- and lowdose edoxaban compared with warfarin [25]. These data demonstrate that DOACs are effective in both VKA-naïve and -experienced patients.

In the RE-LY trial, 1270 patients underwent cardioversion: 647, 672, and 664 in the dabigatran $110 \mathrm{mg}$, dabigatran $150 \mathrm{mg}$, and warfarin groups, respectively. Rates of stroke and SEE were $0.8,0.3$, and $0.6 \%$, respectively, at 30 days [45]. Rates of major bleeding were 1.7, 0.6, and $0.6 \%$, respectively. Cardioversion or $\mathrm{AF}$ ablation was completed in 321 patients in ROCKET AF [46]. Rates of stroke or SEE (1.88 vs. $1.86 \%)$ and death (1.88 vs. $3.73 \%)$ were similar between rivaroxaban-treated and warfarin-treated patients, respectively [46]. In a prospective randomized trial of rivaroxaban in patients with $\mathrm{AF}$ undergoing elective cardioversion, rivaroxaban was associated with a significantly shorter time to cardioversion and was associated with similar rates of major bleeding compared to VKAs [47]. During ARISTOTLE, 743 cardioversions occurred in 540 patients; 265 receiving apixaban and 275 receiving warfarin. No stroke or SEE occurred during the 30-day follow-up in these patients. There was one incident of MI, one of major bleeding, and two deaths in each treatment group [48]. These results represent a small number of patients, but demonstrate that DOACs are a reasonable alternative to warfarin in patients requiring cardioversion.

\section{Determining Risk and Guideline Recommendations}

Stratification schemes are available to quantify the risk of stroke in patients with AF (Table 7). The $\mathrm{CHADS}_{2}$ score assigns 1 point each for the presence of chronic heart failure, hypertension, age $\geq 75$ years, and diabetes mellitus; and 2 points for history of stroke or TIA [33]. For each 1-point increase in the $\mathrm{CHADS}_{2}$ score, stroke rate increases by a factor of 1.5 (95\% CI 1.3-1.7) per $100 \mathrm{PY}$ without antithrombotic therapy [33]. Patients with no risk factors can be managed with aspirin or no antithrombotic therapy [33]. Patients with AF who have one definitive risk factor or have two or more combination risk factors should be considered for oral anticoagulation [49].

To better identify patients with AF who are at low and moderate risk for stroke, the $\mathrm{CHADS}_{2}$ score has been refined to incorporate additional risk factors and is now referred to as the $\mathrm{CHA}_{2} \mathrm{DS}_{2}$-VASc score (Table 7) $[49,50]$. As such, the $\mathrm{CHA}_{2} \mathrm{DS}_{2}$-VASc is now the preferred mode for assessing stroke risk $[8,9]$.

Current guidelines for the management of AF from the American Heart Association/American College of Cardiology/Heart Rhythm Society (AHA/ACC/HRS) and the European Society of Cardiology (ESC) recommend DOACs or warfarin for prevention of thromboembolism in nonvalvular $\mathrm{AF}$ patients with prior stroke, TIA, or $\mathrm{CHA}_{2} \mathrm{DS}_{2}$-VASc score $\geq 2$, with consideration of risk of stroke, risk of bleeding, and patient preferences $[8,9]$. No antithrombotic therapy is recommended for patients with a score of $0[8,9]$. With moderate to severe chronic kidney disease, reduced doses of DOACs may be considered, although not in patients with end-stage chronic kidney disease [8]. Warfarin is recommended for patients with $\mathrm{CrCl}<15 \mathrm{~mL} / \mathrm{min}$ or on hemodialysis who have a $\mathrm{CHA}_{2} \mathrm{DS}_{2}$-VASc score $\geq 2$ [8]. In addition, ESC recommends that oral anticoagulation should be considered in patients with scores as low as 1, upon assessment of the risk of bleeding complications and patient preferences. The ESC recommends one of the DOACs rather than a doseadjusted VKA for most patients when oral anticoagulation is recommended [9]. The AHA/ACC/HRS recommends DOACs over warfarin only for patients who are unable to maintain a therapeutic INR [8].

Stroke risk is also closely linked to bleeding risk. The use of the HAS-BLED score improves the predictive accuracy of bleeding risk and can be used in conjunction with stroke risk scores to determine if anticoagulant therapy should be initiated in patients with AF who are not undergoing antithrombotic therapy or if antiplatelet therapy is under consideration [51]. A score $\geq 3$ indicates a patient who is potentially at high risk for bleeding events [51]. HAS-BLED demonstrates good predictive accuracy overall, with a better predictive accuracy for patients receiving either no antithrombotic therapy or antiplatelet therapy [51]. The ESC recommends the use of the HAS-BLED bleeding risk stratification scheme in conjunction with the use of $\mathrm{CHA}_{2} \mathrm{DS}_{2}$-VASc [9]. However, it should be noted that there is limited validation for the use of HAS-BLED. 
Table 7 Risk stratification scoring schema $[8,51]$

\begin{tabular}{|c|c|c|c|}
\hline \multicolumn{2}{|l|}{$\mathrm{CHADS}_{2}$} & \multicolumn{2}{|l|}{$\mathrm{CHA}_{2} \mathrm{DS}_{2-}$ VASc } \\
\hline Clinical Characteristic & Points awarded & Clinical characteristic & Points awarded \\
\hline Congestive heart failure & 1 & Congestive heart failure & 1 \\
\hline Hypertension & 1 & Hypertension & 1 \\
\hline Age $>75$ years & 1 & Age $>75$ years & 2 \\
\hline Diabetes mellitus & 1 & Diabetes mellitus & 1 \\
\hline Prior stroke/TIA/Thromboembolism & 2 & Prior stroke/TIA/thromboembolism & 2 \\
\hline \multirow[t]{4}{*}{ Maximum score } & 6 & Vascular disease (prior MI, PAD, aortic plaque) & 1 \\
\hline & & Age $65-75$ years & 1 \\
\hline & & Sex category (female) & 1 \\
\hline & & Maximum score & 9 \\
\hline \multicolumn{4}{|l|}{ HAS-BLED } \\
\hline \multicolumn{2}{|l|}{ Clinical characteristic } & & Points awarded \\
\hline \multicolumn{2}{|l|}{ Hypertension } & & 1 \\
\hline \multicolumn{2}{|c|}{ Abnormal renal and liver function (1 point each) } & & 1 or 2 \\
\hline \multicolumn{2}{|l|}{ Stroke } & & 1 \\
\hline \multicolumn{2}{|l|}{ Bleeding } & & 1 \\
\hline \multicolumn{2}{|l|}{ Labile INRs } & & 1 \\
\hline \multicolumn{2}{|l|}{ Elderly } & & 1 \\
\hline \multicolumn{2}{|l|}{ Drugs or alcohol (1 point each) } & & 1 or 2 \\
\hline \multicolumn{2}{|l|}{ Maximum score } & & 9 \\
\hline
\end{tabular}

INR international normalized ratio, $M I$ myocardial infarction, $P A D$ peripheral artery disease, TIA transient ischemic attack

Further, bleeding risk should not be used as a reason to exclude or discontinue anticoagulation [52], and patients at a high risk for stroke rarely have a bleeding risk exceeding their risk of stroke [53, 54].

\section{Discussion}

A superficial review of these trial results may convince clinicians that there are differences between the results of these agents for certain endpoints that were evaluated. While this may be a tempting conclusion, it is critical that clinicians understand that differences in the study designs and study populations make this extremely difficult.

The trials used different populations of patients in the statistical determination of noninferiority to warfarin in their primary endpoints (i.e. ITT, mITT, or per protocol). In an ITT design, the randomized subjects are analyzed in the groups to which they were assigned regardless of whether they received or adhered to their treatment. In ENGAGE-AF, the treatment period was the period between administration of the first dose of the study drug and either three days after the receipt of the last dose or the end of the double-blind therapy. Events were censored during study-drug interruptions that lasted more than three days. In the ROCKET AF study "per-protocol" "on-treatment," only subjects who fulfilled the protocol in terms of the eligibility, interventions, and outcome assessment were analyzed. This restricts the treatment comparisons to the ideal patients who adhered perfectly to the protocol stipulations. For the practicing clinician, evaluating patient adherence and the likelihood of therapy interruptions may be an important consideration in drug selection and anticipated outcomes.

Use of ITT versus on-treatment populations for noninferiority studies is controversial [55] and the FDA recommends that results for noninferiority analyses be reported for both populations [56]. The inclusion of all patients randomized to treatment in the ITT population avoids biases associated with switching treatment, dropout patterns, or patient selection. However, these analyses also include patient outcomes that occur after patients have ceased treatment, and include patients with poor adherence. However, exclusion of patients who have dropped out of a study, in the on-treatment population, can introduce bias toward noninferiority. Thus, when the results are robust for both populations in a study, noninferiority is firmly established $[55,56]$. Alternately, discrepancies between the ITT 
and on-treatment noninferiority analyses can suggest an inclusion bias and that exclusion of patients from the ontreatment population was treatment-related [55]. Only the ROCKET AF trial reported noninferiority for both ontreatment and ITT populations; $p<0.001$ for both (Table 5).

While each of these agents has demonstrated an impressive outcome that may seem to separate it from the pack, there are also concerns that challenge this potential advantage. Dabigatran and apixaban were the only two agents to demonstrate superiority in the ITT analysis, and rivaroxaban and edoxaban did so only in the per-protocol and mITT analyses, respectively. These results may be suggestive that dabigatran and apixaban are more effective agents for the prevention of stroke and SEE in patients with nonvalvular AF. While this could be true, there are other factors that should be considered (Table 4). It is important to note that in the RE-LY and ARISTOTLE trials, the mean $\mathrm{CHADS}_{2}$ score was only 2.2 and 2.1, respectively. By comparison, patients in the ROCKET AF and ENGAGE AF trials had a higher risk of stroke with mean $\mathrm{CHADS}_{2}$ score of 3.5 and 2.8, respectively. Patients with a $\mathrm{CHADS}_{2}$ score of 0 or 1 , who may not even need anticoagulant therapy, made up about one-third of the total patients in RE-LY and ARISTOTLE, and only three patients in ROCKET AF had this level of low risk. In comparison, about one-third of patients in RE-LY and ARISTOTLE were high-risk, with a CHADS 2 score of $\geq 3$. The ROCKET AF trial had $87 \%$ of patients in this highrisk group. Patients in RE-LY and ARISTOTLE consistently had lower incidence of all components of the $\mathrm{CHADS}_{2}$ score compared with patients in ROCKET AF and ENGAGE AF (Table 4). Therefore, differences in patient populations studied are important to consider when evaluating these results.

In addition to differences in the patient populations studied, a recent reinterpretation of the DOAC phase 3 trial results suggest that the failure of rivaroxaban and higherdose regimen edoxaban to demonstrate superiority over warfarin in their ITT analyses of the primary efficacy endpoint may be due to an imbalance of off-treatment events in the DOAC arms compared with the warfarin arms. These high discontinuation rates, coupled with more off-treatment events, would dilute the benefits of the treatment effect in the ITT analyses [57].

While all of the DOACs provided a significant reduction in hemorrhagic stroke in the trials, only dabigatran provided a significant reduction in the rates of ischemic stroke compared with warfarin (Table 5). In RE-LY, warfarin was administered in an open-label manner and INR was monitored and adjusted locally. In the other three trials, due to their double-blind, double-dummy designs, INR monitoring was done through standardized, encrypted, point-of- care devices that provide INR reading (real or sham) to the site investigators. This difference may result in greater variability in warfarin control at the individual patient level when warfarin is administered open-label compared with blinded, as demonstrated in an analysis of the SPORTIF (Stroke Prevention Using Thrombin Inhibitor in Atrial Fibrillation) III (open-label) and V (blinded) trials [58]. While the rate of stroke and SEE was $1.2 \%$ for ximelagatran in both studies, the efficacy outcome occurred in $2.3 \%$ of patients receiving open-label warfarin in the SPORTIF III trial, but improved to $1.2 \%$ with blinded warfarin in the SPORTIF V trial. Therefore, open-label warfarin resulted in a stroke and SEE rate that was almost twice that of blinded warfarin [58]. Thus, it may be that in RE-LY there was greater individual INR variability that contributed to the higher ischemic stroke rate observed in the warfarin treatment group. It should also be noted that in more recent trials, such as RE-LY, warfarin management was dictated by a nomogram or algorithm [22]. Therefore, fluctuations in outcomes in warfarin therapy may be less dramatic as in the older SPORTIF trials. This may explain why the TTR was lower in the ROCKET AF trial than the other DOAC trials. While investigators in the RE-LY, ARISTOTLE, and ENGAGE AF trials were provided guidance on warfarin management, investigators in the ROCKET AF trial were not and managed warfarin according to their usual practice [22-25].

The ROCKET AF patient population had the highest risk of stroke compared to the other trials, but the efficacy of rivaroxaban was not superior to warfarin based on the ITT analysis. Apixaban, with patients at lower risk for stroke (based on mean $\mathrm{CHADS}_{2}$ score) demonstrated superior efficacy over warfarin in its ITT analysis. However, the absolute differences in event rates in ROCKET AF and ARISTOTLE are the same. The trials also calculated the important outcome of major bleeding over different periods of time. Both apixaban and either dose of edoxaban significantly reduced major bleeding rates compared with warfarin, whereas rivaroxaban and dabigatran demonstrated similar rates of major bleeding compared with warfarin. While this may be due to truly better safety with apixaban and edoxaban, it may also be due to how bleeding events were accrued. In the ARISTOTLE and ENGAGE AF trials, bleeding events were only included if they occurred 2 or 3 days, respectively, after last dose. In the RE-LY and ROCKET AF trials, bleeding events were recorded over the duration of the study for both dabigatran and rivaroxaban.

Based on the differences discussed here, it seems difficult to suggest that one agent has a defined benefit over another in patients with nonvalvular AF. Therefore, a collective review of these data as a class of agents may be most appropriate. A meta-analysis of all 71,683 
participants in the RE-LY, ROCKET AF, ARISTOTLE, and ENGAGE AF trials compared DOACs to warfarin [40]. Stroke or SEE were reduced by $19 \%$ by DOACs compared with warfarin (RR, 0.81; $95 \%$ CI 0.73-0.91; $p<0.0001)$. DOACs significantly reduced all-cause mortality (RR, $0.90 ; 95 \%$ CI $0.85-0.95 ; p=0.0003$ ) and intracranial hemorrhage (RR, 0.48; $95 \%$ CI $0.39-0.59$; $p<0.0001$ ), but increased gastrointestinal bleeding (RR, 1.25 ; $95 \%$ CI $1.01-1.55 ; p=0.04$ ) [40]. Finally, in an analysis of the net clinical benefit of the DOACs compared with warfarin based on the phase 3 clinical trials, each DOAC evaluated had a favorable net clinical benefit in comparison with warfarin [59]. All four DOACs had significant net clinical benefit for the composite of disabling stroke plus life-threatening bleeding [59].

As clinicians decide on the optimal DOAC for reducing the risk of stroke in a patient with $\mathrm{AF}$, patient adherence should be considered. It is unlikely that patients who are nonadherent to warfarin therapy would be adherent with a DOAC, although DOACs may be advantageous in patients where nonadherence results or occurs because of frequent warfarin monitoring requirements. Another issue to consider in adherence is dosing frequency. In a study of 103 anticoagulation clinic patients, 11 patients were found to be nonadherent within 3 months of initiation of twice-daily dabigatran. Adherence was defined as taking $>80 \%$ of required doses [60]. There were also $30 \%$ of patients who reported missing doses during this time frame, with one reporting missing a dose every day [60]. An additional study of 5376 Veterans Affairs' patients evaluated adherence of twice-daily dabigatran and found a connection to outcomes. Using the same definition of adherence as the previous study, $28 \%$ of patients were found to be nonadherent to dabigatran therapy. The investigators determined that for every $10 \%$ decrease in adherence there was an associated $13 \%$ increased risk of stroke and all-cause mortality [61]. Therefore, once-daily DOAC therapy may be preferred to twice-daily therapy in patients in whom adherence with a more complex regimen might be a concern. While there are no comparable data to show that adherence with once-daily is better than twice-daily DOAC therapy, adherence with once-daily cardiovascular medications are typically better than twice-daily medications [62]. Data on DOAC persistence are limited. Registry data suggest that rivaroxaban persistence was greater than VKA persistence, with few discontinuations due to thromboembolic complications, although bleeding was the most frequent reason for discontinuation [63]. In the same registry, rates of discontinuation of dabigatran were comparable to rates for VKA, and dabigatran discontinuation was primarily due to gastrointestinal side effects [64].

Limited post-marketing data are available for dabigatran. A comparison of bleeding rates for dabigatran and warfarin using insurance-claim data and administrative data from the FDA Mini-Sentinel database demonstrated similar bleeding rates for these medications from October 19, 2010 (dabigatran approval date), to December 31, 2011 [65]. In patients with $\mathrm{AF}$, the incidence of gastrointestinal hemorrhage in patients who received dabigatran was 1.6 per 100,000 days at risk compared with 3.5 per 100,000 days at risk in patients who received warfarin. Similarly, the intracranial hemorrhage rate was 0.8 per 100,000 days at risk in patients who received dabigatran and 2.4 per 100,000 days at risk in patients who received warfarin [65]. To date, the dabigatran post-marketing data mirror trial results [66].

Post-marketing data are also available for rivaroxaban from the Department of Defense electronic medical record [67]. Data were collected from January 1, 2013, to March 31,2014 , in 27,467 patients with nonvalvular AF to evaluate major bleeding. The incidence of major bleeding in these patients was 2.9 per $100 \mathrm{PY}$, which is similar to the 3.6 per $100 \mathrm{PY}$ demonstrated in the ROCKET AF trial. Use of rivaroxaban in a "real world" setting does not seem to be associated with an increased risk of major bleeding.

In a recent literature review, 26 published cases of severe hemorrhagic complications with dabigatran and two such cases for rivaroxaban were presented [68]. Cases were assessed for three risk factors of hemorrhagic complications: (1) prescriber error; (2) renal impairment; or (3) age $>80$ years with body weight $<60 \mathrm{~kg}$. At least one of these three risk factors was present in $78 \%$ of cases [68]. This suggests that clinicians must make informed choices in determining the appropriate DOAC for each patient. In summary, the introduction of DOACs, while simplifying treatment, may generate additional controversy because DOAC trials were different enough from each other that direct comparison among them is not possible.

\section{Conclusion}

The DOACs provide further options for patients with nonvalvular $\mathrm{AF}$ at risk for stroke in addition to traditional therapy with warfarin. The clinician has several individual patient factors to consider including risk factors, tolerability, patient preference, potential for drug interaction, and other clinical characteristics. The DOACs have demonstrated efficacy and safety that are similar to or better than warfarin in large, randomized clinical trials and are valuable alternatives to warfarin in patients with nonvalvular AF.

Acknowledgements Editorial support was provided by Terri Schochet, PhD; and Meryl Gersh, PhD; of AlphaBioCom, LLC, King of Prussia, PA, USA. AlphaBioCom has received funding from Daiichi Sankyo, Inc., Parsippany, NJ, USA. 


\section{Compliance with Ethical Standards}

Funding source No funding was requested or received for the preparation of this manuscript by the authors.

Conflict of interest Dr. Dobesh has served as a consultant for Pfizer/BMS, Janssen Pharmaceuticals, and Daiichi Sankyo. He has also received research funding from Daiichi Sankyo. Dr. Fanikos has served as a consultant for Boehringer Ingelheim and Portola Pharmaceuticals.

Open Access This article is distributed under the terms of the Creative Commons Attribution-NonCommercial 4.0 International License (http://creativecommons.org/licenses/by-nc/4.0/), which permits any noncommercial use, distribution, and reproduction in any medium, provided you give appropriate credit to the original author(s) and the source, provide a link to the Creative Commons license, and indicate if changes were made.

\section{References}

1. Go AS, Hylek EM, Phillips KA, Chang Y, Henault LE, Selby JV, et al. Prevalence of diagnosed atrial fibrillation in adults: national implications for rhythm management and stroke prevention: the AnTicoagulation and Risk Factors in Atrial Fibrillation (ATRIA) Study. JAMA. 2001;285(18):2370-5.

2. Piccini JP, Hammill BG, Sinner MF, Jensen PN, Hernandez AF, Heckbert SR, et al. Incidence and prevalence of atrial fibrillation and associated mortality among Medicare beneficiaries, 1993-2007. Circ Cardiovasc Qual Outcomes. 2012;5(1):85-93. doi:10.1161/CIRCOUTCOMES.111.962688.

3. Roger VL, Go AS, Lloyd-Jones DM, Benjamin EJ, Berry JD, Borden WB, et al. Heart disease and stroke statistics-2012 update: a report from the American Heart Association. Circulation. 2012;125(1):e2-220. doi:10.1161/CIR.0b013e31823ac046.

4. van Walraven C, Hart RG, Connolly S, Austin PC, Mant J, Hobbs $\mathrm{FD}$, et al. Effect of age on stroke prevention therapy in patients with atrial fibrillation: the atrial fibrillation investigators. Stroke. 2009;40(4):1410-6. doi:10.1161/STROKEAHA.108.526988.

5. Wolf PA, Abbott RD, Kannel WB. Atrial fibrillation as an independent risk factor for stroke: the Framingham Study. Stroke. 1991;22(8):983-8.

6. Marini C, De Santis F, Sacco S, Russo T, Olivieri L, Totaro R, et al. Contribution of atrial fibrillation to incidence and outcome of ischemic stroke: results from a population-based study. Stroke. 2005;36(6):1115-9. doi:10.1161/01.STR.0000166053.83476.4a.

7. Ogilvie IM, Newton N, Welner SA, Cowell W, Lip GY. Underuse of oral anticoagulants in atrial fibrillation: a systematic review. Am J Med. 2010;123(7):638 e4-645 e4. doi:10.1016/j. amjmed.2009.11.025.

8. January CT, Wann LS, Alpert JS, Calkins H, Cigarroa JE, Cleveland JC Jr, et al. 2014 AHA/ACC/HRS Guideline for the Management of Patients With Atrial Fibrillation: Executive Summary: A Report of the American College of Cardiology/ American Heart Association Task Force on Practice Guidelines and the Heart Rhythm Society. Circulation. 2014;130(23):2071-104. doi:10.1161/CIR.0000000000000040.

9. Camm AJ, Lip GY, De Caterina R, Savelieva I, Atar D, Hohnloser SH, et al. 2012 focused update of the ESC Guidelines for the management of atrial fibrillation: an update of the 2010 ESC Guidelines for the management of atrial fibrillation. Developed with the special contribution of the European Heart Rhythm Association. Eur Heart J. 2012;33(21):2719-47. doi:10.1093/ eurheartj/ehs 253 .
10. ELIQUIS ${ }^{\circledR}$ (apixaban) tablet, film coated [package insert]. Full Prescribing Information. Princeton, NJ: Bristol-Myers Squibb. 2015.

11. PRADAXA ${ }^{\circledR}$ (dabigatran etexilate mesylate). Full Prescribing Information. Ridgefield, CT: Boehringer Ingelheim Pharmaceuticals, Inc. 2015 .

12. XARELTO ${ }^{\circledR}$ (rivaroxaban) tablets. Full prescribing information. Titusville, NJ: Janssen Pharmaceutical, Inc. 2015.

13. SAVAYSA ${ }^{\mathrm{TM}}$ (edoxaban) tablets for oral use. Full Prescribing Information. Parsippany, NJ: Daiichi Sankyo Inc. 2015.

14. Hart RG, Pearce LA, Aguilar MI. Meta-analysis: antithrombotic therapy to prevent stroke in patients who have nonvalvular atrial fibrillation. Ann Intern Med. 2007;146(12):857-67.

15. Ansell J, Hirsh J, Hylek E, Jacobson A, Crowther M, Palareti G, et al. Pharmacology and management of the vitamin K antagonists: American College of Chest Physicians Evidence-Based Clinical Practice Guidelines (8th Edition). Chest. 2008;133(6 Suppl):160S-98S. doi:10.1378/chest.08-0670.

16. Connolly SJ, Pogue J, Eikelboom J, Flaker G, Commerford P, Franzosi MG, et al. Benefit of oral anticoagulant over antiplatelet therapy in atrial fibrillation depends on the quality of international normalized ratio control achieved by centers and countries as measured by time in therapeutic range. Circulation. 2008;118(20):2029-37. doi:10.1161/circulationaha.107.750000.

17. Agarwal S, Hachamovitch R, Menon V. Current trial-associated outcomes with warfarin in prevention of stroke in patients with nonvalvular atrial fibrillation: a meta-analysis. Arch Intern Med. 2012;172(8):623-31. doi:10.1001/archinternmed.2012.121 (discussion 31-33).

18. Ghate SR, Biskupiak J, Ye X, Kwong WJ, Brixner DI. All-cause and bleeding-related health care costs in warfarin-treated patients with atrial fibrillation. J Manag Care Pharm. 2011;17(9):672-84.

19. Piazza G, Nguyen TN, Cios D, Labreche M, Hohlfelder B, Fanikos J, et al. Anticoagulation-associated adverse drug events. Am J Med. 2011;124(12):1136-42. doi:10.1016/j.amjmed.2011. 06.009 .

20. O'Brien EC, Holmes DN, Ansell JE, Allen LA, Hylek E, Kowey $\mathrm{PR}$, et al. Physician practices regarding contraindications to oral anticoagulation in atrial fibrillation: findings from the Outcomes Registry for Better Informed Treatment of Atrial Fibrillation (ORBIT-AF) registry. Am Heart J. 2014;167(4):601 e1-609 e1. doi:10.1016/j.ahj.2013.12.014.

21. Gonzalez-Quesada CJ, Giugliano RP. Comparison of the phase III clinical trial designs of novel oral anticoagulants versus warfarin for the treatment of nonvalvular atrial fibrillation: implications for clinical practice. Am J Cardiovasc Drugs. 2014;12(2):111-27.

22. Connolly SJ, Ezekowitz MD, Yusuf S, Eikelboom J, Oldgren J, Parekh A, et al. Dabigatran versus warfarin in patients with atrial fibrillation. N Engl J Med. 2009;361(12):1139-51. doi:10.1056/ NEJMoa0905561.

23. Granger CB, Alexander JH, McMurray JJ, Lopes RD, Hylek EM, Hanna M, et al. Apixaban versus warfarin in patients with atrial fibrillation. N Engl J Med. 2011;365(11):981-92. doi:10.1056/ NEJMoa1107039.

24. Patel MR, Mahaffey KW, Garg J, Pan G, Singer DE, Hacke W, et al. Rivaroxaban versus warfarin in nonvalvular atrial fibrillation. N Engl J Med. 2011;365(10):883-91. doi:10.1056/ NEJMoa1009638.

25. Giugliano RP, Ruff CT, Braunwald E, Murphy SA, Wiviott SD, Halperin JL, et al. Edoxaban versus warfarin in patients with atrial fibrillation. N Engl J Med. 2013;369(22):2093-104. doi:10. 1056/NEJMoa1310907.

26. Ruff CT, Giugliano RP, Antman EM, Crugnale SE, Bocanegra T, Mercuri M, et al. Evaluation of the novel factor Xa inhibitor edoxaban compared with warfarin in patients with atrial 
fibrillation: design and rationale for the Effective aNticoaGulation with factor $\mathrm{xA}$ next GEneration in Atrial FibrillationThrombolysis In Myocardial Infarction study 48 (ENGAGE AFTIMI 48). Am Heart J. 2010;160(4):635-41. doi:10.1016/j.ahj. 2010.06.042.

27. Connolly SJ, Ezekowitz MD, Yusuf S, Reilly PA, Wallentin L. Randomized evaluation of long-term anticoagulation therapy I. Newly identified events in the RE-LY trial. N Engl J Med. 2010;363(19):1875-6. doi:10.1056/NEJMc1007378.

28. Connolly SJ, Wallentin L, Yusuf S. Additional events in the RELY trial. N Engl J Med. 2014;371(15):1464-5. doi:10.1056/ NEJMc1407908.

29. PRADAXA ${ }^{\circledR}$ [monograph]. Burlington, Ontario: Boehringer-Ingelheim Canada Ltd. 2014. http://boehringer-ingelheim.ca/ content/dam/internet/opu/ca_EN/documents/humanhealth/product_ monograph/PradaxaPMEN.pdf. Accessed 10 Dec 2014.

30. European Medicines Agency. Pradaxa (dabigatran). European Public Assessment Report (EPAR) Product Information. http://www.ema. europa.eu/docs/en_GB/document_library/EPAR__Product_Inform ation/human/000829/WC500041059.pdf (updated March 19, 2014). Accessed 4 June 2014.

31. LIXIANA ${ }^{\circledR}$ edoxaban tosilate hydrate tablets[package insert]. Daiichi Sankyo Co. Ltd. Tokyo, Japan. 2014.

32. LIXIANA ${ }^{\circledR}$ (edoxaban). Package Leaflet. Daiichi Sankyo Europe GmbH. Munich, Germany. 2015.

33. Gage BF, Waterman AD, Shannon W, Boechler M, Rich MW, Radford MJ. Validation of clinical classification schemes for predicting stroke: results from the National Registry of Atrial Fibrillation. JAMA. 2001;285(22):2864-70.

34. Diener HC, Connolly SJ, Ezekowitz MD, Wallentin L, Reilly PA, Yang S, et al. Dabigatran compared with warfarin in patients with atrial fibrillation and previous transient ischaemic attack or stroke: a subgroup analysis of the RE-LY trial. Lancet Neurol. 2010;9(12):1157-63. doi:10.1016/S1474-4422(10)70274-X.

35. Hankey GJ, Patel MR, Stevens SR, Becker RC, Breithardt G, Carolei A, et al. Rivaroxaban compared with warfarin in patients with atrial fibrillation and previous stroke or transient ischaemic attack: a subgroup analysis of ROCKET AF. Lancet Neurol. 2012;11(4):315-22. doi:10.1016/S1474-4422(12)70042-X.

36. Verbeeck RK, Musuamba FT. Pharmacokinetics and dosage adjustment in patients with renal dysfunction. Eur J Clin Pharmacol. 2009;65(8):757-73. doi:10.1007/s00228-009-0678-8.

37. US Food and Drug Administration. Guidance for industry. Pharmacokinetics in patients with impaired renal function-study design, data analysis, and impact on dosing and labeling. March $2010 . \quad$ http://www.fda.gov/downloads/Drugs/Guidances/ UCM204959.pdf. Accessed 4 April 2014. 2010.

38. Fox KA, Piccini JP, Wojdyla D, Becker RC, Halperin JL, Nessel $\mathrm{CC}$, et al. Prevention of stroke and systemic embolism with rivaroxaban compared with warfarin in patients with non-valvular atrial fibrillation and moderate renal impairment. Eur Heart J. 2011;32(19):2387-94. doi:10.1093/eurheartj/ehr342.

39. US Food and Drug Administration. SAVAYSA (edoxaban) Tablets. FDA Draft Briefing Document for the Cardiovascular and Renal Drugs Advisory Committee. NDA 206316. Meeting date October 30, 2014. http://www.fda.gov/AdvisoryCommittees/ CommitteesMeetingMaterials/Drugs/CardiovascularandRenalDr ugsAdvisoryCommittee/ucm420703.htm. 2014.

40. Ruff CT, Giugliano RP, Braunwald E, Hoffman EB, Deenadayalu $\mathrm{N}$, Ezekowitz MD, et al. Comparison of the efficacy and safety of new oral anticoagulants with warfarin in patients with atrial fibrillation: a meta-analysis of randomised trials. Lancet. 2014;383(9921):955-62. doi:10.1016/S0140-6736(13)62343-0.

41. Eikelboom JW, Wallentin L, Connolly SJ, Ezekowitz M, Healey JS, Oldgren J, et al. Risk of bleeding with 2 doses of dabigatran compared with warfarin in older and younger patients with atrial fibrillation: an analysis of the randomized evaluation of long-term anticoagulant therapy (RE-LY) trial. Circulation. 2011;123(21): 2363-72. doi:10.1161/CIRCULATIONAHA.110.004747.

42. Kato ET, Giugliano RP, Ruff CT, Murphy SA, Nordio F, Kimura $T$, et al. Efficacy and safety of edoxaban for management of elderly patients with atrial fibrillation: ENGAGE AF-TIMI 48. Circulation. 2014;130:A16612.

43. Ezekowitz MD, Wallentin L, Connolly SJ, Parekh A, Chernick MR, Pogue J, et al. Dabigatran and warfarin in vitamin $\mathrm{K}$ antagonist-naive and -experienced cohorts with atrial fibrillation. Circulation. 2010;122(22):2246-53. doi:10.1161/ CIRCULATIONAHA.110.973735.

44. Mahaffey KW, Wojdyla D, Hankey GJ, White HD, Nessel CC, Piccini JP, et al. Clinical outcomes with rivaroxaban in patients transitioned from vitamin $\mathrm{K}$ antagonist therapy: a subgroup analysis of a randomized trial. Ann Intern Med. 2013;158(12):861-8. doi:10.7326/0003-4819-158-12201306180-00003.

45. Nagarakanti R, Ezekowitz MD, Oldgren J, Yang S, Chernick M, Aikens TH, et al. Dabigatran versus warfarin in patients with atrial fibrillation: an analysis of patients undergoing cardioversion. Circulation. 2011;123(2):131-6. doi:10.1161/ CIRCULATIONAHA.110.977546.

46. Piccini JP, Stevens SR, Lokhnygina Y, Patel MR, Halperin JL, Singer DE, et al. Outcomes after cardioversion and atrial fibrillation ablation in patients treated with rivaroxaban and warfarin in the ROCKET AF trial. $\mathrm{J}$ Am Coll Cardiol. 2013;61(19):1998-2006. doi:10.1016/j.jacc.2013.02.025.

47. Cappato R, Ezekowitz MD, Klein AL, Camm AJ, Ma CS, Le Heuzey JY, et al. Rivaroxaban vs. vitamin K antagonists for cardioversion in atrial fibrillation. Eur Heart $J$. 2014;35(47):3346-55. doi:10.1093/eurheartj/ehu367.

48. Flaker G, Lopes RD, Al-Khatib SM, Hermosillo AG, Hohnloser $\mathrm{SH}$, Tinga B, et al. Efficacy and safety of apixaban in patients after cardioversion for atrial fibrillation: insights from the ARISTOTLE Trial (Apixaban for Reduction in Stroke and Other Thromboembolic Events in Atrial Fibrillation). J Am Coll Cardiol. 2014;63(11):1082-7. doi:10.1016/j.jacc.2013.09.062.

49. Lip GY, Nieuwlaat R, Pisters R, Lane DA, Crijns HJ. Refining clinical risk stratification for predicting stroke and thromboembolism in atrial fibrillation using a novel risk factor-based approach: the euro heart survey on atrial fibrillation. Chest. 2010;137(2):263-72. doi:10.1378/chest.09-1584.

50. Friberg L, Rosenqvist M, Lip GY. Evaluation of risk stratification schemes for ischaemic stroke and bleeding in 182678 patients with atrial fibrillation: the Swedish Atrial Fibrillation cohort study. Eur Heart J. 2012;33(12):1500-10. doi:10.1093/eurheartj/ ehr488.

51. Pisters R, Lane DA, Nieuwlaat R, de Vos CB, Crijns HJ, Lip GY. A novel user-friendly score (HAS-BLED) to assess 1-year risk of major bleeding in patients with atrial fibrillation: the Euro Heart Survey. Chest. 2010;138(5):1093-100. doi:10.1378/chest.100134.

52. Dzeshka MS, Lane DA, Lip GY. Stroke and bleeding risk in atrial fibrillation: navigating the alphabet soup of risk-score acronyms (CHADS2, CHA2 DS2 -VASc, R2 CHADS2, HAS-BLED, ATRIA, and more). Clin Cardiol. 2014;37(10):634-44. doi:10. 1002/clc.22294.

53. Barnes GD, Gu X, Haymart B, Kline-Rogers E, Almany S, Kozlowski J, et al. The predictive ability of the CHADS2 and CHA2DS2-VASc scores for bleeding risk in atrial fibrillation: the MAQI(2) experience. Thromb Res. 2014;134(2):294-9. doi:10. 1016/j.thromres.2014.05.034.

54. Roldan V, Marin F, Fernandez H, Manzano-Fernandez S, Gallego $\mathrm{P}$, Valdes $\mathrm{M}$, et al. Predictive value of the HAS-BLED and ATRIA bleeding scores for the risk of serious bleeding in a "real- 
world" population with atrial fibrillation receiving anticoagulant therapy. Chest. 2013;143(1):179-84. doi:10.1378/chest.12-0608.

55. Walker E, Nowacki AS. Understanding equivalence and noninferiority testing. J Gen Intern Med. 2011;26(2):192-6. doi:10. 1007/s11606-010-1513-8.

56. US Food and Drug Administration. Guidance for industry. NonInferiority Clinical Trials. March 2010. http://www.fda.gov/ Drugs/GuidanceComplianceRegulatoryInformation/Guidances/ ucm064981.htm. Accessed 04 Dec 2014. 2010.

57. Chan NC, Paikin JS, Hirsh J, Lauw MN, Eikelboom JW, Ginsberg JS. New oral anticoagulants for stroke prevention in atrial fibrillation: impact of study design, double counting and unexpected findings on interpretation of study results and conclusions. Thromb Haemost. 2014;111(5):798-807. doi:10.1160/TH13-110918.

58. Hylek EM, Frison L, Henault LE, Cupples A. Disparate stroke rates on warfarin among contemporaneous cohorts with atrial fibrillation: potential insights into risk from a comparative analysis of SPORTIF III versus SPORTIF V. Stroke. 2008;39(11):3009-14. doi:10.1161/STROKEAHA.108.514935.

59. Renda G, di Nicola M, De Caterina R. Net clinical benefit of nonvitamin $\mathrm{K}$ antagonist oral anticoagulants versus warfarin in phase III atrial fibrillation trials. Am J Med. 2015. doi:10.1016/j. amjmed.2015.03.034.

60. Schulman S, Shortt B, Robinson M, Eikelboom JW. Adherence to anticoagulant treatment with dabigatran in a real-world setting. J Thromb Haemost. 2013;11(7):1295-9. doi:10.1111/jth. 12241.

61. Shore S, Carey EP, Turakhia MP, Jackevicius CA, Cunningham F, Pilote L, et al. Adherence to dabigatran therapy and longitudinal patient outcomes: insights from the veterans health administration. Am Heart J. 2014;167(6):810-7. doi:10.1016/j. ahj.2014.03.023.
62. Bae JP, Dobesh PP, Klepser DG, Anderson JD, Zagar AJ, McCollam PL, et al. Adherence and dosing frequency of common medications for cardiovascular patients. Am J Manag Care. 2012;18(3):139-46.

63. Beyer-Westendorf J, Forster K, Ebertz F, Gelbricht V, Schreier T, Gobelt $\mathrm{M}$, et al. Drug persistence with rivaroxaban therapy in atrial fibrillation patients-results from the Dresden non-interventional oral anticoagulation registry. Europace. 2015;17(4):530-8. doi:10.1093/europace/euu319.

64. Beyer-Westendorf J, Ebertz F, Forster K, Gelbricht V, Michalski F, Kohler C, et al. Effectiveness and safety of dabigatran therapy in daily-care patients with atrial fibrillation. Results from the Dresden NOAC Registry. Thromb Haemost. 2015;113(6):1247-57. doi:10.1160/TH14-11-0954.

65. Southworth MR, Reichman ME, Unger EF. Dabigatran and postmarketing reports of bleeding. $\mathrm{N}$ Engl $\mathrm{J}$ Med. 2013;368(14):1272-4. doi:10.1056/NEJMp1302834.

66. Thelus R, Villnes TC, Coster TS. Dabigatran versus warfarin among patients with atrial fibrillation: real-world post-market results. Circulation. 2012;126:Abstract A14877.

67. Tamayo S, Peacock WF, Patel M, Sicignano N, Hopf KP, Fields LE, et al. Characterizing major bleeding in patients with nonvalvular atrial fibrillation: a pharmacovigilance study of 27467 patients taking rivaroxaban. Clin Cardiol. 2015;38(2):63-8. doi:10.1002/clc.22373.

68. Pfeilschifter W, Luger S, Brunkhorst R, Lindhoff-Last E, Foerch C. The gap between trial data and clinical practice-an analysis of case reports on bleeding complications occurring under dabigatran and rivaroxaban anticoagulation. Cerebrovasc Dis. 2013;36(2):115-9. doi:10.1159/000352062. 